Review

\title{
Current Status, Scenario, and Prospective of Renewable Energy in Algeria: A Review
}

\author{
Younes Zahraoui ${ }^{1, *(\mathbb{D})}$, M. Reyasudin Basir Khan ${ }^{2}\left(\mathbb{D}\right.$, Ibrahim AlHamrouni ${ }^{1}$, Saad Mekhilef ${ }^{3,4,5}$ (D) \\ and Mahrous Ahmed 6 (D)
}

1 British Malaysian Institute, Universiti Kuala Lumpur, Bt. 8, Jalan Sungai Pusu, Selangor 53100, Malaysia; ibrahim.mohamed@unikl.edu.my

2 School of Engineering, Manipal International University, No. 1, Persiaran MIU, Putra Nilai 71800, Negeri Sembilan, Malaysia; mohammed.reyasudin@miu.edu.my

3 Power Electronics and Renewable Energy Research, Laboratory, Department of Electrical Engineering, University of Malaya, Kuala Lumpur 50603, Malaysia; saad@um.edu.my

4 School of Software and Electrical Engineering, Faculty of Science, Engineering and Technology, Swinburne University of Technology, Melbourne, VIC 3122, Australia

5 Center of Research Excellence in Renewable Energy and Power Systems, King Abdulaziz University, Jeddah 21589, Saudi Arabia

6 Electrical Engineering Department, College of Engineering, Taif University, Taif 21944, Saudi Arabia; m.elsamman@tu.edu.sa

* Correspondence: Zahraoui.younes@s.unikl.edu.my or younessetif@live.fr

check for updates

Citation: Zahraoui, Y.; Basir Khan, M.R.; AlHamrouni, I.; Mekhilef, S.; Ahmed, M. Current Status, Scenario, and Prospective of Renewable Energy in Algeria: A Review. Energies 2021, 14, 2354. https://doi.org/10.3390/ en14092354

Academic Editor: J. C. Hernandez

Received: 6 March 2021

Accepted: 29 March 2021

Published: 21 April 2021

Publisher's Note: MDPI stays neutral with regard to jurisdictional claims in published maps and institutional affiliations.

Copyright: (c) 2021 by the authors. Licensee MDPI, Basel, Switzerland. This article is an open access article distributed under the terms and conditions of the Creative Commons Attribution (CC BY) license (https:/ / creativecommons.org/licenses/by/ $4.0 /)$.
Abstract: Energy demand has been overgrowing in developing countries. Moreover, the fluctuation of fuel prices is a primary concern faced by many countries that highly rely on conventional power generation to meet the load demand. Hence, the need to use alternative resources, such as renewable energy, is crucial in order to mitigate fossil fuel dependency, while ensuring reductions in carbon dioxide emissions. Algeria-being the largest county in Africa-has experienced a rapid growth in energy demand over the past decade due to the significant increase in residential, commercial, and industry sectors. Currently, the hydrocarbon-rich nation is highly dependent on fossil fuels for electricity generation, with renewable energy only having a small contribution to the country's energy mix. However, the country has massive potential for renewable energy generation, such as solar, wind, biomass, geothermal, and hydropower. Therefore, the government aims to diversify away from fossil fuels and promote renewable energy generation through policies and renewable energy-related programs. The country's Renewable Energy and Energy Efficiency Development Plan focuses on large scale solar, wind generation as well as geothermal and biomass technologies. This paper provides an update on the current energy position and renewable energy status in Algeria. Moreover, this paper discusses renewable energy (RE) policies and programs that aim to increase the country's renewable energy generation and its implementation status.

Keywords: Algeria; renewable energy; solar; wind; biomass; hydro; geothermal

\section{Introduction}

Highlights:

- Algeria has great potential for solar, wind, hydro, geothermal and bio-power energy generation;

- Algeria aims to include $27 \%$ of renewable energy generation in their energy mix by 2030;

- the country is progressing slowly in terms of renewable energy development, as of 2021.

- $\quad$ Algeria is focusing on increasing solar generation by 2030.

The consumption of electrical power has been continuously increasing due to the rapid growth of the population and economy. Total global energy consumption increased by $2.9 \%$ 
in 2018, reaching 26,700 TWh in 2018, whereas global energy production rose 30\% from 2016 to 2018 [1,2]. The United Nations Human Development Index (HDI) proposes that growth in energy consumption up to around 100 Gigajoules (GJ) per person is linked with the substantial increase in human development and comfort. Fossil fuels contributed to almost $75 \%$ of the global electricity requirements in 2018, leading to increased carbon dioxide $\left(\mathrm{CO}_{2}\right)$ emissions. On the other hand, the Intergovernmental Panel on Climate Change (IPCC) reported the global average temperature on the Earth's surface has increased by $0.2{ }^{\circ} \mathrm{C}$ to $0.6^{\circ} \mathrm{C}$, resulting in the disappearance of ice sheets, massive changes in vegetation, regional extinctions and a sea-level rise of about $120 \mathrm{~m}$ [3]. Hence, it is crucial to reduce $\mathrm{CO}_{2}$ emission through the introduction of renewable energy (RE) generation methods in order to replace fossil fuel generation. Since a decade ago, many countries have implemented green energy economies with goals and policies to increase their RE generation and reduce fossil fuel consumption [4]. In 2018, 169 countries had RE goals, and 150 countries had dedicated funds for RE research and development with supportive policies [1].

Algeria is located in the Sunbelt, which has a high potential for solar energy. In 2011, the Algerian Ministry of Energy and Mining (MEM) introduced the law No. 11-11 to fund and support RE projects and lay the groundwork for future RE programs and sustainable development in the country. This law is considered a new incentive to commence initiatives to minimize the excessive consumption of conventional energy sources that are related to higher $\mathrm{CO}_{2}$ emissions and fluctuations in oil and gas prices [5].

Several researchers have provided updates on the RE status in Algeria. For example, A. Boudghene Stambouli provided a review on the energy development in Algeria in 2012 [6,7]. The author discussed the country's energy scenario, alongside exploring the potential of solar and wind for reducing the dependency on fossil fuels. Other studies related to Algeria's energy status have focused on the relationship between renewable and non-RE that contributes to high $\mathrm{CO}_{2}$ emissions, such as [8]. Recently, a study was conducted on Algeria's RE status and policies $[9,10]$. However, these studies have not provided an in-depth analysis of Algeria's current RE capacity and generation, but rather, they have focused on RE future targets and policies.

Moreover, they have also heavily relied on old reports and the literature from past decades. There are also discrepancies between the energy data provided by these sources. Therefore, this article's goal is to collect, compile, summarize, and analyze the data from sources such as reports, scientific articles, and online news articles related to the subject of RE in Algeria.

To the best of the author's knowledge, there has been no comprehensive review on the status and perspective of RE in Algeria since 2012. Hence, this paper will provide recent updates on current RE installation, potential, and policies. This paper is structured as follows: Section 2 provides information on the data collection sources. Section 3 provides information on the current global energy status. An introduction to Algeria's geography, demographics, and a status update on energy in the country is discussed in Section 4. Section 5 reviews Algeria's RE potential in the form of solar, wind, hydropower, geothermal, and biomass. Meanwhile, Section 6 summarizes the energy stakeholders in the country. Section 7 focuses on policies and programs for RE. Section 8 highlights the status of the country's RE development and installation. Additionally, the social, economic, and environmental status of RE development in the country is presented in Section 9. Finally, Section 10 summarizes the findings and provides insights into the strategies implemented to increase RE generation in the country.

\section{Data Collection}

This work mainly explores the status of RE in Algeria and the implementation of its laws, regulations, and programs. Additionally, this study includes the potential for RE installation in the country. The information gathered in this study was collected and summarized from official published reports. The main reports used as a reference in this study are listed below: 
(a) World Energy Outlook 2019 by the International Energy Agency (IEA) [2]

(b) International Energy Outlook 2019 by the U.S Energy Information Administration [11]

(c) BP Statistical Review of World Energy 2019 [12]

(d) Renewables Global Status Reports (2015-2020) by the Renewable Energy Policy Network for the 21st Century (REN 21) [1,13-17]

(e) World Energy Issues Monitor Reports (2015-2020) by the World Energy Council [4,18-22]

(f) Algeria Special Report 2020 by the Africa Energy Series [23]

(g) Hydropower Status Reports (2015-2020) by the International Hydropower Association Limited (IHA) [24-29]

(h) National Energy Report and Renewable Energy and Energy Efficiency Program report by the Ministry of Energy and Mining (MEM), Algeria [30,31]

(i) National Renewable Energy Program 2015-2030 report by Shariket Kahraba wa Taket Moutadjadida, (SKTM), which is Sonelgaz holding's electricity generation subsidiary [32].

Other resources related to the latest RE news in the country were obtained from online reports and scientific articles.

\section{Global Energy Status}

Global energy demand has been growing from 2011 to 2018 by approximately $30 \%$ and is expected double by 2022 [1]. Hence, many countries are moving toward RE to reduce dependency on fossil fuels and to mitigate $\mathrm{CO}_{2}$ emissions. Many countries have shown interest in RE sources in order to meet their energy demands. Huge investment alongside new policies and RE programs were introduced in developing countries for generation diversification and to shift to higher RE penetration. Nowadays, the cost of RE technologies is at an all-time low compared to past decades [6]. Moreover, the abundance of renewable resources such as solar irradiation, wind, geothermal, and biomass has led to interest by governments to reconsider the usage of renewable energies instead of conventional fossil fuels [6].

Figure 1 shows the global energy mix in 2019 [1]. Fossil fuels contributed $72.7 \%$ of the total global generation, with RE contributing $27.3 \%$. The global fossil fuel mix reduced by $2.8 \%$, complemented by RE sources for the past three years [33]. The RE contribution to global energy is increasing in each year as compared to the previous year. Hydropower contributed $58 \%$ of the total global RE generation in 2019, followed by wind (21.6\%), solar photovoltaic (PV) (10.3\%), bio-power $(8 \%)$ and other generation sources, such as geothermal, concentrated solar thermal power (CSP) and ocean power contributed $1.5 \%$. The year 2019 recorded the most significant increase in RE capacity due to reducing project expenses, significant investments, and the development of technology in the field. Additionally, global funding of RE has been increasing throughout the years, leading to higher levels of RE generation [1,34]. More than $200 \mathrm{GW}$ of RE has been added this year, contributing toward a total of $2588 \mathrm{GW}$ of RE installed capacity. The distribution of the global RE technology mix is shown in Figure 2. 


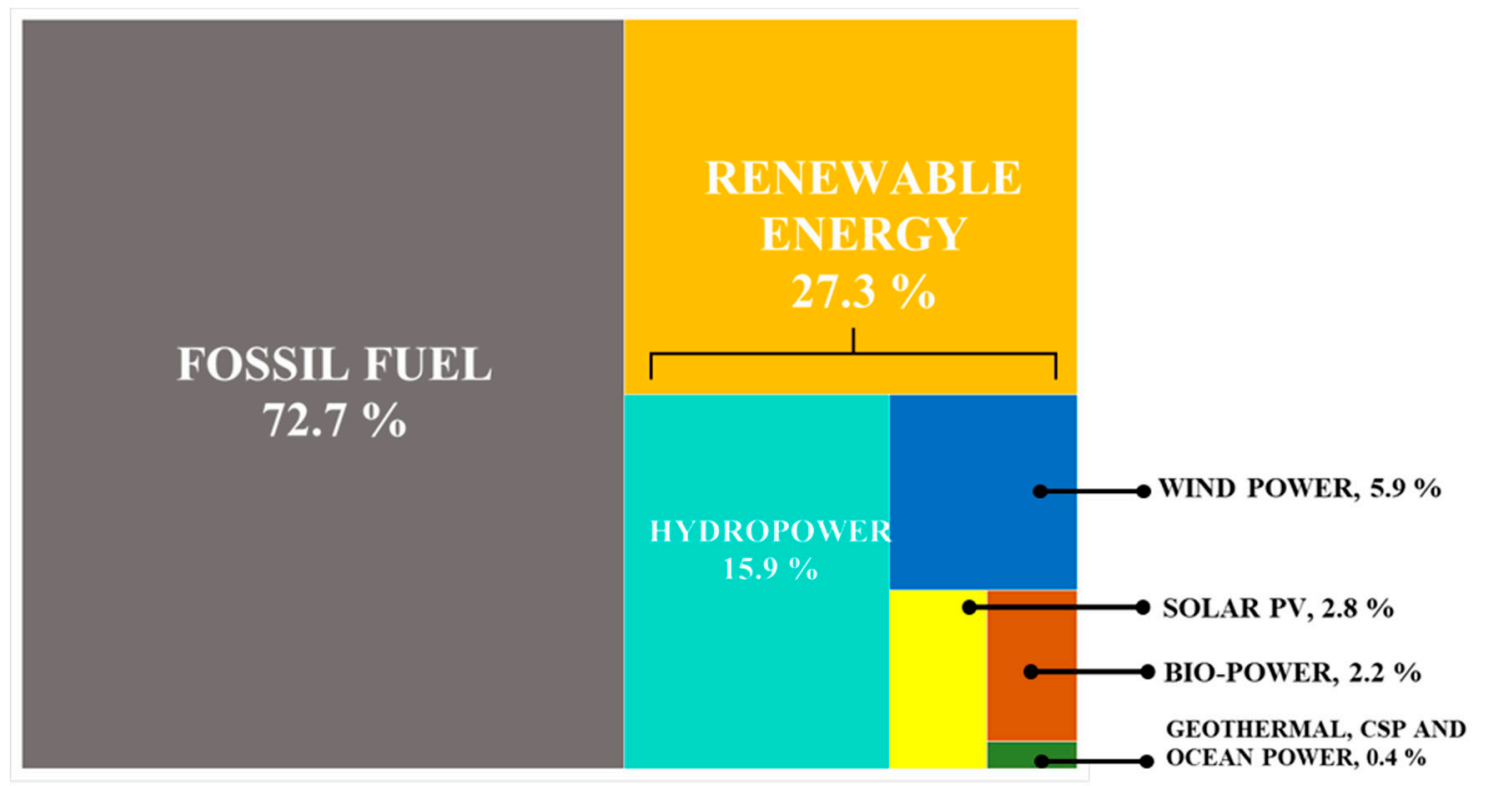

Figure 1. Global Energy Mix, 2019.

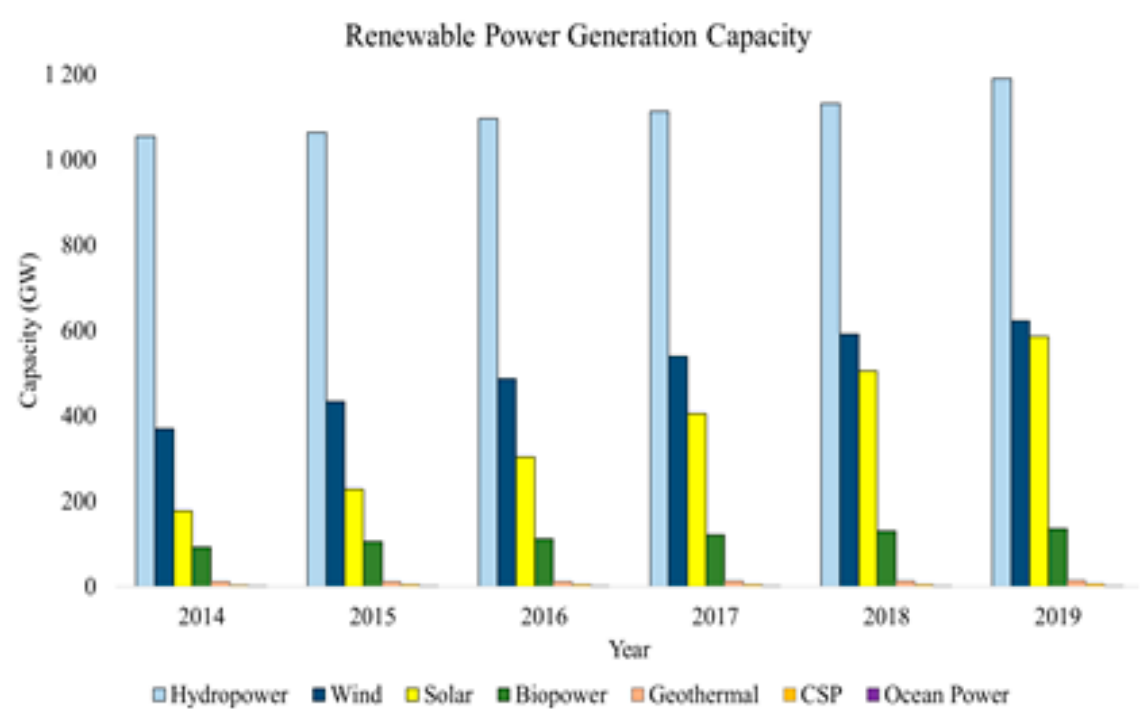

Figure 2. Global renewable energy (RE) generation capacity.

\subsection{Hydropower}

Hydropower is energy derived from falling or moving water [28]. Hydropower stations vary in terms of type, storage, size, and the height of the water. Generally, hydropower is classified based on its generation capacity, where small hydro is a scheme below $10 \mathrm{MW}$, mini-hydro is a scheme below $2 \mathrm{MW}$, micro-hydro is a scheme below $500 \mathrm{~kW}$, and pico-hydro is a scheme below $10 \mathrm{~kW}$ [35-37]. Hydropower plays an essential role in RE and in global energy production, contributing 15.9\% to the global power in 2019 with a total capacity of $1150 \mathrm{GW}$ [28,38]. Hydropower generation rose by $1.4 \%$ in 2019 from $1134 \mathrm{GW}$ to $1150 \mathrm{GW}[1,28]$. The investment in large hydropower plants has been accompanied by an obvious increase in world energy consumption through an increase in demand over the last ten years.

\subsection{Wind}

Wind energy is contemplated as one of the most efficient technologies in RE generation. The system uses kinetic energy from the wind to turn turbines for power generation [39]. 
The amount of wind energy available varies daily and seasonally. The total amount of wind energy able to be harnessed significantly depends on the characteristics, performance, and size of the wind turbines [6,39]. The total global wind generation in 2019 was $651 \mathrm{GW}$, representing a $10.2 \%$ increase from 2018 [40,41].

\subsection{Solar}

Solar PV uses PV modules to convert energy from the sun into electricity [1]. Solar PV contributes $2.8 \%$ to the total global energy. PV generation increased by $115 \mathrm{GW}(22.5 \%)$ in 2019 from 512 GW to 627 GW, as shown in Figure 2 [42]. Hence, it has become the world's fastest-growing RE energy technology, and is the most expanded and competitive in the power generation market, through facilities such as adequate frameworks and policies offered by the governments of most countries $[39,43]$.

\subsection{Bio-Power}

Bio-power includes solid biomass, liquid biofuels, biogas, and landfill gas [1]. This technology uses materials such as biomass to generate electricity or heat through methods such as direct firing, cofiring, anaerobic digestion, pyrolysis, and gasification [1]. Bio-power is a spatially spread resource. Bio-power has also been shown to produce high greenhouse gas emissions but at levels less than its fuel fossil counterpart [1]. Bio-power contributed $2.2 \%$ to the total global power generation in 2019. The bio-power generation capacity was $136 \mathrm{GW}$ in 2019, representing a 4.6\% increase from $130 \mathrm{GW}$ in 2018 [1].

\subsection{Geothermal}

Geothermal is a technology that harnesses heat from the Earth's sub-surface [44]. Geothermal energy has a high efficiency with an average capacity factor of around 74.5\%, and with the implementation of new technology, it can attain $90 \%$ in the ideal site. The estimated geothermal reserve could supply the global world for around 217 million years [45]. Geothermal energy has various applications, including penetration and heating systems. In 2019 , global geothermal power generation capacity reached $14 \mathrm{GW}$, representing a 5.3\% increase from the year 2018.

\subsection{Concentrating Solar Power (CSP)}

Concentrating solar power (CSP) generates electrical power with mirrors to reflect a large amount of sunlight to a receiver, that will be heated to drive a steam turbine connected to a generator [46]. The CSP capacity was 6.45 GW in 2019, with an 18\% increase from 2018. Thus, CSP represents the energy source that has shown the most significant increment since 2014. Since the cost to build new CSP plants dropped significantly between 2016 and 2019. Numerous CSP stations have been constructed in parallel with solar PV plants [1].

\subsection{Ocean Power}

Ocean power belongs to technologies that generate energy from the ocean through tidal streams, tidal range, ocean waves, the salinity gradient, and temperature gradients [47]. In this paper, ocean power does not include marine biomass and offshore wind power. This technology represents the smallest RE contribution with small scale projects. In 2019, ocean power generation capacity was $532 \mathrm{MW}$ and had been stagnant for the past three years [1]. Although the ocean power resource is vast, it is mostly untapped due to the immature technologies available.

\section{Energy Status in Algeria}

Algeria is the largest county in Africa and the 10th largest in the world. It has an area of $2,381,741 \mathrm{~km}^{2}$ and an estimated population of 42.2 million people, with an average of 17.71 inhabitants $/ \mathrm{km}^{2}$ [48]. It is located in the north of Africa with a $1644 \mathrm{~km}$ long coastline, as shown in Figure 3 [49]. The Southern part of the country consists of a significant portion of the Sahara Desert. This region is hot year around. However, the coastal area 
of the country is mountainous and hilly, with an average rainfall of 400 to $670 \mathrm{~mm}$ and temperatures ranges from $25^{\circ} \mathrm{C}$ to $11^{\circ} \mathrm{C}$.

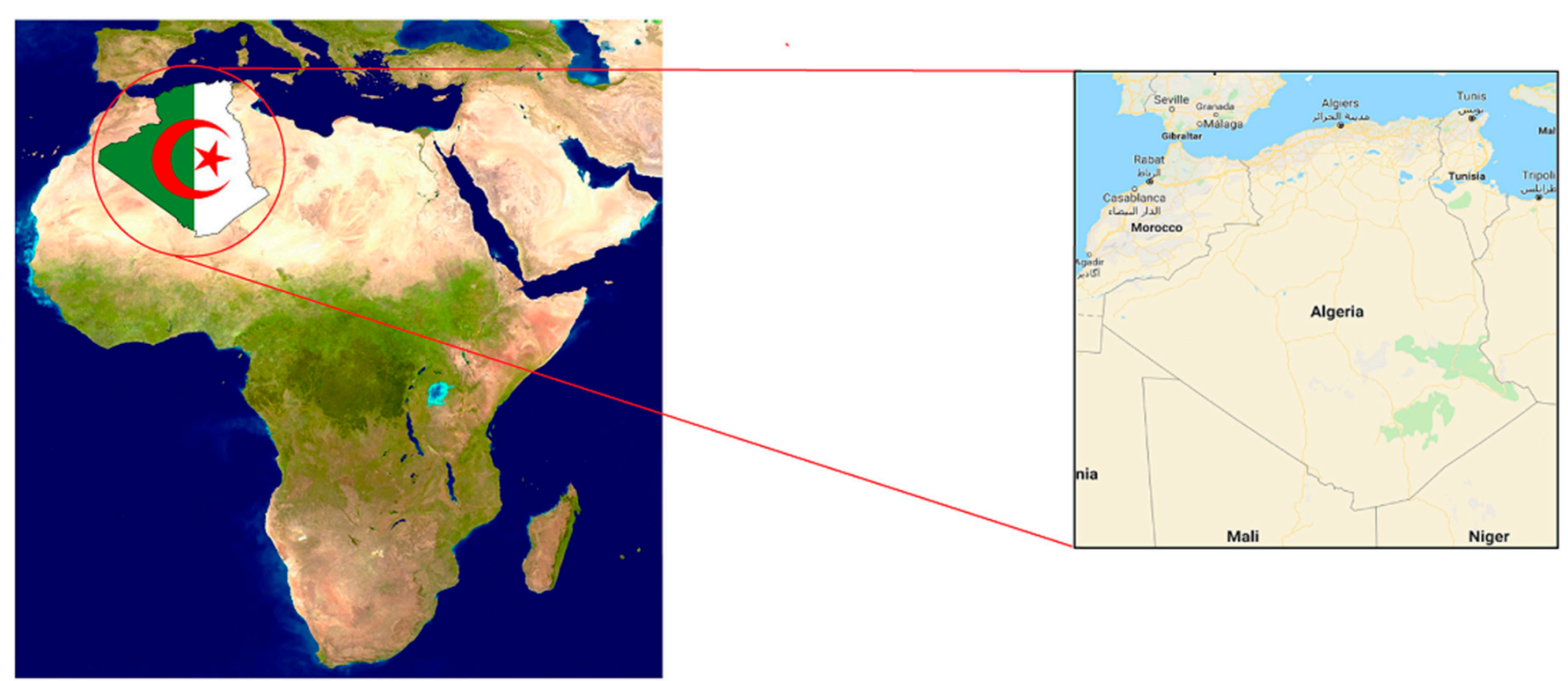

Figure 3. Algeria's location in Africa.

Algeria has the 4th most influential economy in Africa, with a Gross Domestic Product (GDP) of USD 178.3 billion [50]. The country's economy is mainly based on the production and export of oil and gas. Sonatrach is a national company responsible for the hydrocarbon sector. Algeria is among the countries that have an abundance of fossil and fuels and is a member of the Organization of Petroleum Exporting Countries (OPEC) [51,52]. Oil and Gas basins in the country are located in seven areas: the Ghedames and Illizi basins in the east; the Timimoun, Ahnet and Mouydir basins in the central region; the Reggane and Tindouf basins in the southwest, as illustrated in Figure 4 [50]. The country has the 3rd most extensive reserves of gas and the 7th most significant oil reserves in the world. In 2018, Algeria produced 12.2 billion barrels and 159 trillion cubic feet (Tcf) of oil and natural gas reserves, respectively [34].

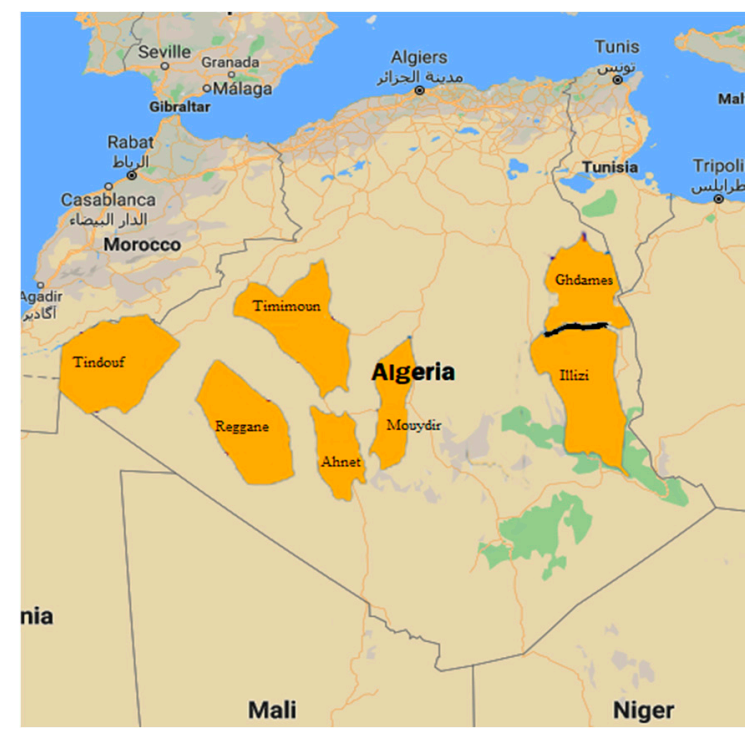

Figure 4. The location of gas and oil basins in Algeria. 
Figure 5 shows the current energy mix of Algeria. The country relies heavily on fossil fuels-such as natural gas and oil, which contribute $64.84 \%$ and $34.63 \%$, respectively-for electricity generation. Algeria showed substantial growth in the production of gas, and oil from the year 2000 to 2018, contributable to a $33.3 \%$ increase in the population [40,51]. Although $28 \%$ of Algeria's population is located in rural areas, $100 \%$ of households in the country have access to electricity [48].

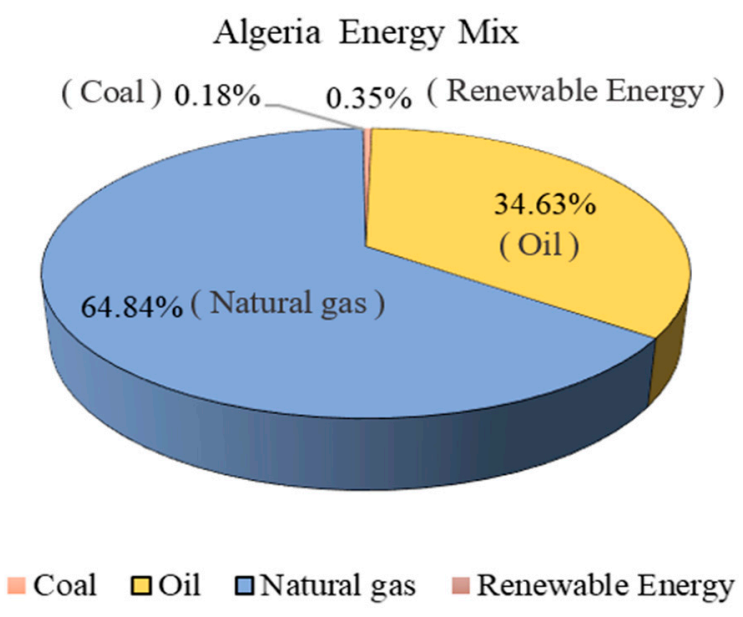

Figure 5. Algeria fossil fuel generation mix in 2019.

The government launched the hydrocarbon law in July 2011 to increase competitiveness by easing taxes and encouraging import and export to attract foreign investment. Moreover, Algeria has many oil refineries and gas treatment center projects that have been kicked-off under the supervision of the national oil company Sonatrach [50]. Currently, the Algerian government is seeking to minimize the energy reliance on hydrocarbons, which represent $99.4 \%$ of the country's power generation sources under the petroleum crisis.

Electricity production rose to 76.4 TWh in 2018 from 76.0 TWh in 2017, proportional to the population growth of almost 1 million people [12]. The load demand increased by $7.4 \%$ from 2007 to 2017. The country's population and energy consumption profile are shown in Figure 6. By 2030, generation is expected to rise to approximately $150 \mathrm{TWh}$, with an additional $5.2 \%$ increment each year. The promulgation of the new law No. 02/01 February 2002, corresponding to the distribution of the electricity grid and gas, functioned as a steppingstone for reorganizing the sector and opening the electricity market. The outcome of this law includes significant grid expansion for electricity transmission from the year 2002 to 2015. Moreover, Algeria was is able to export more than $880 \mathrm{GWh}$ of electricity in 2017 to the neighboring countries such as Tunisia and Morocco [53,54].

Due to the increase in energy demand each year, the Sonalgaz company estimated that 34,441 km of transmission lines are planned to be implemented from 2017 to 2027. Currently, $9930 \mathrm{~km}$ transmission lines are under development, with another $24,511 \mathrm{~km}$ planned, which includes national and international interconnections [55]. 


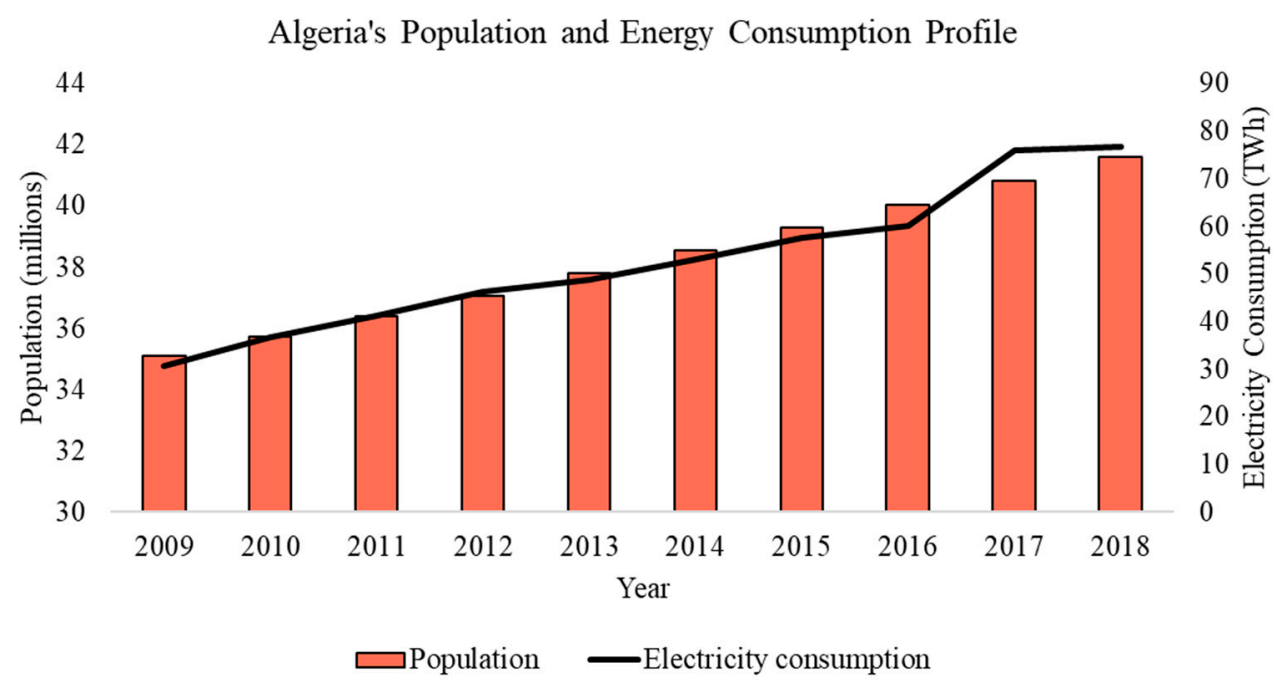

Figure 6. The evolution of population and electricity consumption in Algeria.

\section{RE Potential in Algeria}

The government has been launching policies and funds for RE development in the country since 1998. Algeria has promising RE sources, such as hydropower, wind, geothermal, biomass, and solar, due to its geographical location $[6,56]$.

\subsection{Solar}

The country receives direct irradiation estimated at $169,440 \mathrm{~kW} / \mathrm{m}^{2} /$ year with a potential generation of $3000 \mathrm{kWh} /$ year [53,57]. Table 1 shows the potential for solar generation in Algeria. The desert in the country is considered to be among the areas with high average solar irradiation and temperature globally. The duration of insolation is around 2000 to $3900 \mathrm{~h}$ annually, with horizontal surface radiation of around 3 to $5 \mathrm{kWh} / \mathrm{m}^{2}$. There is a network of 78 meteorological measurement stations operated by the National Meteorological Office (ONM) distributed throughout the country. Figures 7 and 8 show the country's irradiation and temperature distribution [55].

Table 1. Solar potential in Algeria [58].

\begin{tabular}{cccc}
\hline & \multicolumn{3}{c}{ Location } \\
\hline & Coastal Area & Inner Area & Desert Area \\
\hline Surface $(\%)$ & 4 & 10 & 86 \\
Average of the sunrise (hour/year) & 2650 & 3000 & 3500 \\
Average energy received $\left(\mathrm{kWh} / \mathrm{m}^{2} /\right.$ year) & 1700 & 1900 & 2650 \\
\hline
\end{tabular}




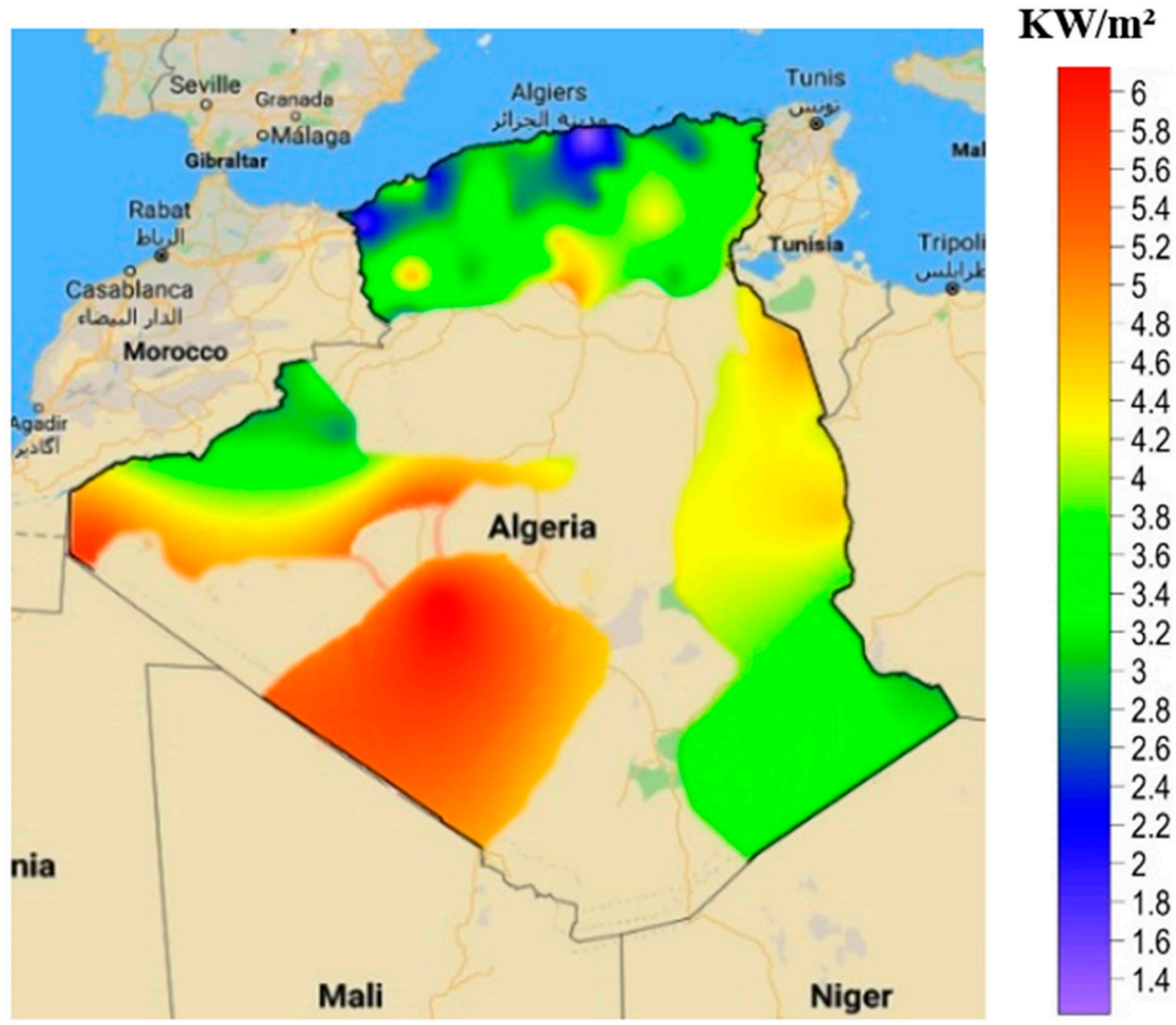

Figure 7. The solar irradiation in Algeria $\mathrm{kW} / \mathrm{m}^{2}$.

Warm desert climate

Cold desert climate

Warm semi-arid climate

Cold semi-arid climate

Warm mediterranean climate

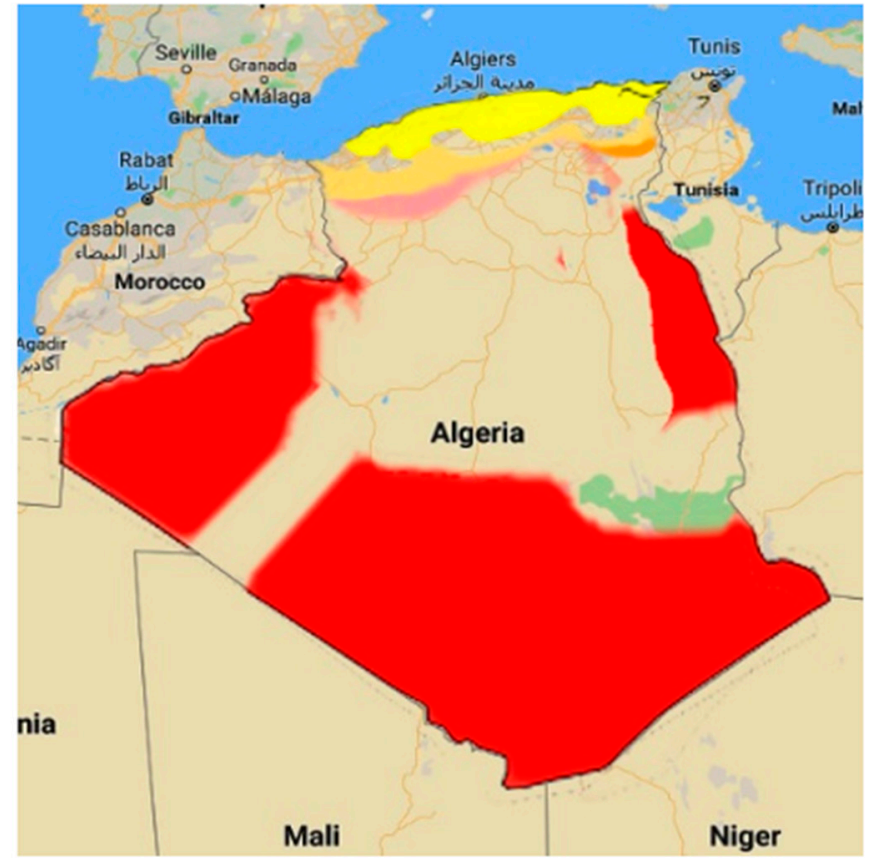

Figure 8. The temperature distribution in Algeria.

The solar generation potential in the desert area of the country is illustrated in Figure 9. The desert area of the country covers $2048.297 \mathrm{~km}^{2}$ of land [33]. This area has the potential to generate $168 \times 1012 \mathrm{kWh} /$ year via utilization of $50 \%$ of the available space factor and an efficiency of $10 \%$. 


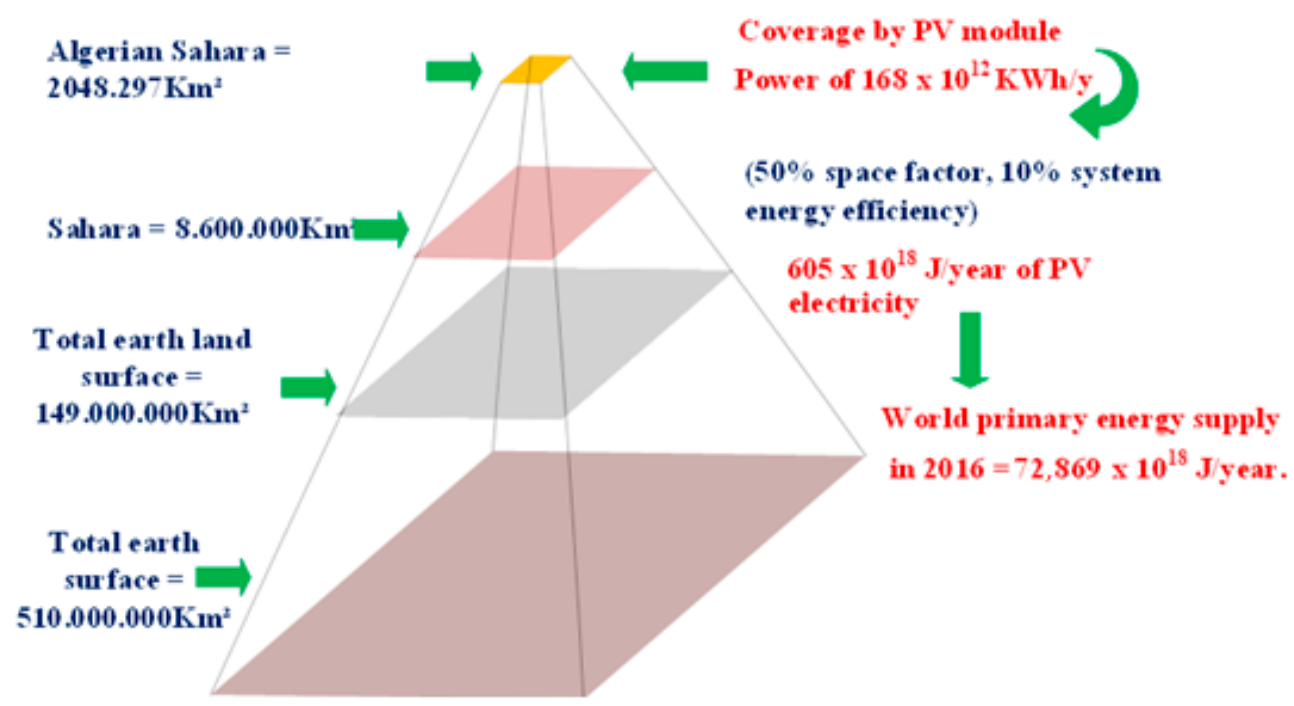

Figure 9. Potential solar generation for the Sahara Desert.

\subsection{Hydropower}

Algeria has promising potential for hydropower generation due to the availability of dam sites and a high average rainfall. Currently, very few studies have investigated the potential of hydropower in the country.

The average rainfall that falls over Algerian territory is estimated at 65 billion cubic meters per annum, with 103 potential dam sites [59]. Figure 10 shows potential sites for dams and rivers that are in the northern region of the country.

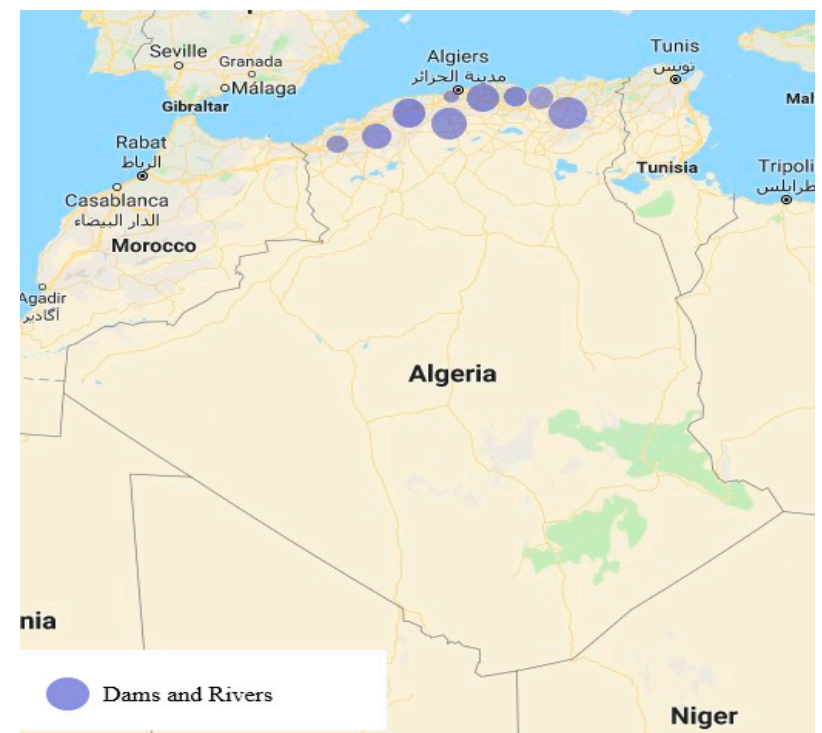

Figure 10. Potential dam and river locations in Algeria for hydropower generation.

\subsection{Wind}

The wind resource in Algeria varies from one location to another based on topography and climate. The country is divided into two distinct geographical areas. The northern region of the country has a coastline of more than $1600 \mathrm{~km}^{2}$ with mountainous topography. Whereas the desert is in the southern region of the country. Several studies have been conducted to analyze the wind power generation potential in the country. Recently, Y. Himri et al. conducted a study to determine the feasibility of wind generation in the south west region of the country [60]. 
Moreover, Djamila Abdeslame studied the wind data measured over ten years from four locations in the country [61]. Additionally, H. Daaou Nedjari et al. from CDER conducted a study to determine the optimal locations for wind generation in the country [62]. The study in [62] by the RE Development Center (CDER) provides a comprehensive study of the wind potential in the country from 74 meteorological stations.

Based on these studies, Algeria has good potential for wind generation in several regions, such as M'Sila, Bou Chekif, Djelfa, and Mecheria. These locations have windy conditions throughout the year, with speeds ranging from 6 to $7 \mathrm{~m} / \mathrm{s}$. Although, there are other locations with high wind speeds, such as In Salah and Adrar, these locations are not suitable for wind generation installation due to geographical conditions and the unavailability of the electrical transmission network. On the other hand, extreme temperatures up to $50{ }^{\circ} \mathrm{C}$ limit installation in the south desert locations in the country. Figure 11 illustrates the available wind speed across regions in the country $[22,63]$.

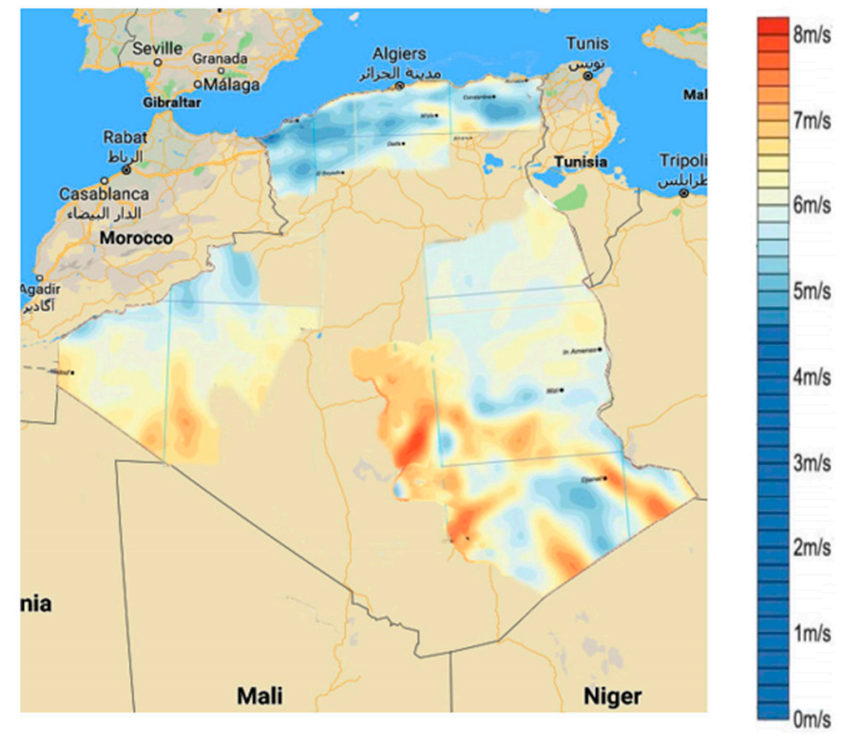

Figure 11. The wind speed potential in Algeria.

\subsection{Geothermal}

Geothermal power is a promising solution to increase RE integration in the country due to the availability of a large number of hot springs [31]. Only limited studies have been published that have investigated the potential geothermal resources in Algeria. For example, Fatima Zohra Kedaid from the CDER developed a database of low-temperature geothermal locations in Algeria, including information such as thematic maps, thermal springs, and hot water resources [64]. Additionally, Hakim Saibi summarized the geothermal data and settings of Algeria from geothermal exploration data available from the CDER [65]. Recently, Abdelkader Ait Ouali et al. conducted studies to evaluate the potential for geothermal energy production in north central Algeria in locations 31 thermal springs in locations such as Ouarsenis, Biban, and Kabylie [66]. Figure 12 illustrates the geothermal potential locations in Algeria.

Based on the studies in $[64,65]$, there are more than 240 hot springs available and distributed from east to west and located at a moderate altitude in the mountainous regions in the country. The highest recorded temperature was $98^{\circ} \mathrm{C}$ for the eastern area, $68{ }^{\circ} \mathrm{C}$ for the western area, and $80^{\circ} \mathrm{C}$ for the central area. Meanwhile, the southern area has an average temperature of $50^{\circ} \mathrm{C}$. Figure 11 shows the available locations for geothermal energy generation in the country. Meanwhile, Figure 13 shows the geothermic chart of 41 hot spring samples in the country. 


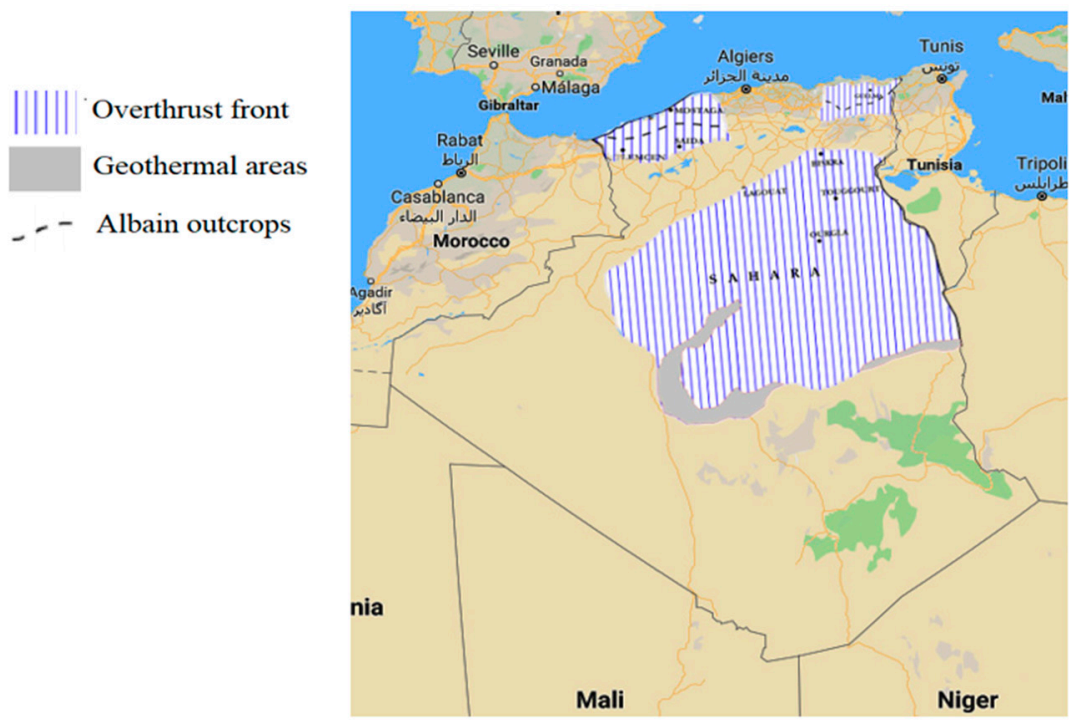

Figure 12. Geothermal potential locations in Algeria.

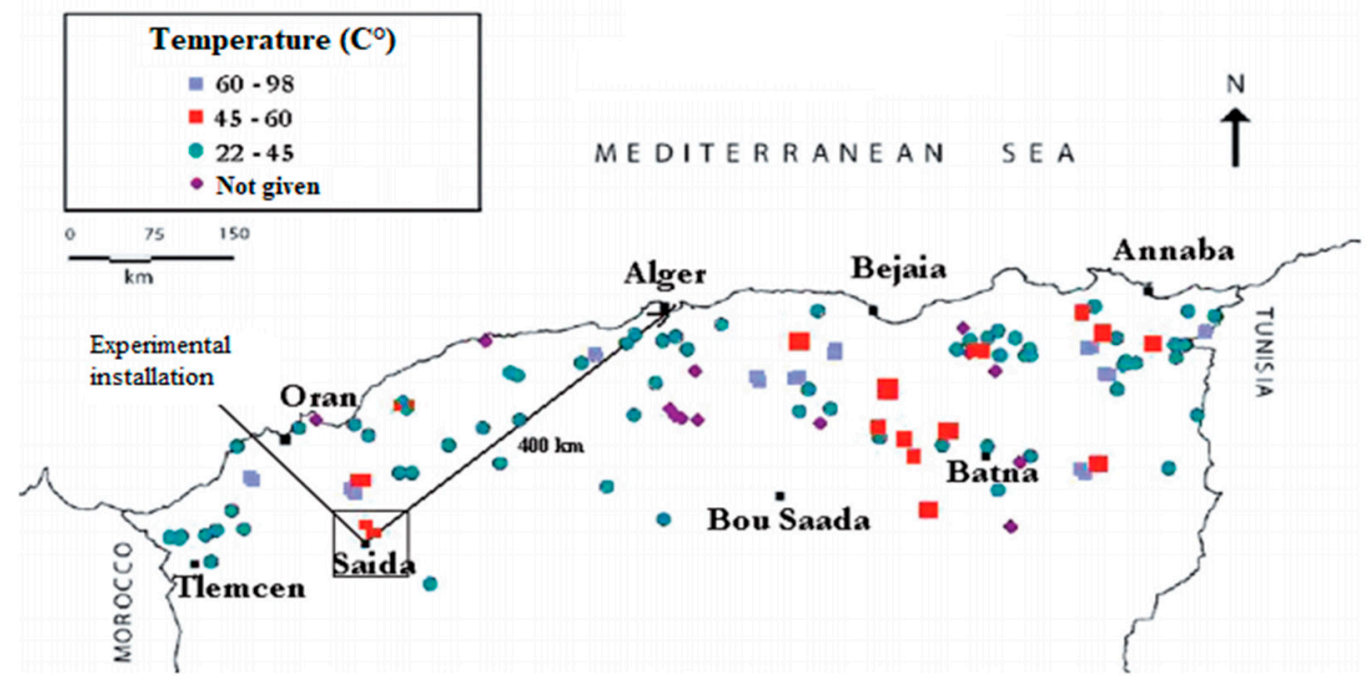

Figure 13. The geothermic chart in Algeria.

The formation of the intercalary continental constitutes a vast number of hot water reservoirs in the southern region of the country. This reservoir, known as the "Albian aquifer", is exploited through boreholes and has an average temperature of $57^{\circ} \mathrm{C}$ and $4 \mathrm{~m}^{3} / \mathrm{s}$ flow, with a potential generation of up to $700 \mathrm{MW}$ [65].

Table 2 shows the locations of hot springs in the country. The Arabic term "Hammam" means hot springs.

Table 2. Thermal source locations in Algeria.

\begin{tabular}{ccc}
\hline Thermal Source & Location & Temperature $\left({ }^{\circ} \mathbf{C}\right)$ \\
\hline Hammam Rabbi & Saïda & 49 \\
Hammam Bouhadjar & Aïn Témouchent & 66.5 \\
Hammam Ain Mentila & Relizane & 31 \\
Hammam Righa & Aïn Defla & 67 \\
Hammam Melouane & Blida & 38.5 \\
Hammam El Mesrane & Djelfa & 42 \\
\hline
\end{tabular}




\subsection{Bio-Power}

Algeria has vast and diversified bio-power resources. The assessment of bio-power resources, such as biomass, is critical for the development of the bioenergy sector in the country. Limited studies have been conducted for assessing the bio-power potential in the country. Amine Akbi from the CDER provided an overview of the potential bioenergy in the country that focuses on domestically available biomass resources for energy generation [67]. Meanwhile, Boukelia Taqiy Eddine and Mecibah Med Salah investigated the potential of solid waste for biomass energy generation in Algeria [68]. The bio-power potential in the country, based on the work conducted in [67], is summarized in Table 3.

Table 3. Potential bio-power in Algeria.

\begin{tabular}{ccc}
\hline Bio-Power Resources & Annual Biogas Potential (Million $\mathbf{~ m}^{\mathbf{3}}$ ) & Potential Energy (GWh) \\
\hline & Agribusiness and industry waste & 17.74 \\
\hline Amurca available from the olive oil industry & 10.5 & 215.5 \\
Pomace available from the olive oil industry & - & 3.97 \\
Whey available from the dairy industry & Urban waste & 1646 \\
\hline & 974 & 38.72 \\
\hline The organic fraction of household waste & 22.91 & 1706.43 \\
\hline TOTAL & 1009.76 & \\
\hline
\end{tabular}

\section{Algeria Energy Stakeholders}

There are several authorities and companies in Algeria that are responsible for the energy landscape in the country. The Ministry of Energy and Mines (MEM) is responsible for the energy policy and addresses issues related to energy generation, transmission, distribution, and consumption in the country. Meanwhile, the Electricity and Gas Regulation Commission (CREG) serves as the regulatory body. At the same time, other energy stakeholders comprise the utility and service companies and other institutions that provide funding, service and research and development works. Government-owned companies such as SONATRACH and SONELGAZ are key players in Algeria's energy sector. The country energy stakeholders are summarized in Table 4.

Table 4. Algerian primary energy stakeholders [10,69].

\begin{tabular}{|c|c|c|}
\hline No. & Authority/Company & Role \\
\hline \multicolumn{3}{|c|}{ Government Bodies and Authorities } \\
\hline 1 & Ministry of Energy and Mines (MEM) & $\begin{array}{l}\text { Responsible for the development of policies and strategies for the } \\
\text { exploitation, production, and usage of energy and mineral resources in } \\
\text { the country. }\end{array}$ \\
\hline 2 & The National Energy Efficiency Fund (FNER) & Provide funds for the development of RE in Algeria \\
\hline 3 & $\begin{array}{c}\text { The National Fund for Energy } \\
\text { Management (FNME) }\end{array}$ & Provide funds for the development of RE in Algeria \\
\hline 4 & $\begin{array}{l}\text { The National Agency for Promotion and } \\
\text { Rationalization of Energy (APRUE) }\end{array}$ & $\begin{array}{l}\text { Promotes and controls the national energy efficiency program and } \\
\text { increases awareness and allocation of information on energy utilization } \\
\text { Responsible for the country's RE production and development. }\end{array}$ \\
\hline 5 & New Energy Algeria (NEAL) & $\begin{array}{c}\text { Moreover, it is also responsible for partnership, consultation for RE, } \\
\text { and energy efficiency projects. }\end{array}$ \\
\hline 6 & $\begin{array}{c}\text { Electricity and Gas Regulation } \\
\text { Commission (CREG) }\end{array}$ & $\begin{array}{c}\text { Responsible for the regulation of electricity and gas for consumers } \\
\text { and operators. }\end{array}$ \\
\hline 7 & $\begin{array}{l}\text { Algerian Institute for Renewable Energies } \\
\text { and Energy Efficiency (IAER) }\end{array}$ & $\begin{array}{l}\text { Institute that facilitates RE and energy efficiency scientific research and } \\
\text { knowledge exchange. }\end{array}$ \\
\hline 8 & RE Development Center (CDER) & Conducts scientific activities for RE development in the country. \\
\hline
\end{tabular}


Table 4. Cont

\begin{tabular}{|c|c|c|}
\hline No. & Authority/Company & Role \\
\hline \multicolumn{3}{|r|}{ Utilities } \\
\hline 1 & SONATRACH & $\begin{array}{l}\text { A national company responsible for the hydrocarbon reserves and the } \\
\text { oil industry. }\end{array}$ \\
\hline 2 & SONELGAZ & $\begin{array}{c}\text { A national company responsible for the production, transport, and } \\
\text { distribution of electricity. }\end{array}$ \\
\hline 3 & Algerian Energy Company (AEC) & $\begin{array}{l}\text { An association between SONELGAZ and SONATRACH with primary } \\
\text { responsibility for production, commercialization, transportation, and } \\
\text { distribution of electricity in Algeria. }\end{array}$ \\
\hline 4 & $\begin{array}{c}\text { Algerian Electricity Production } \\
\text { Company (SPE) }\end{array}$ & $\begin{array}{c}\text { SONELGAZ subsidiary company is responsible for } \\
\text { producing electricity. }\end{array}$ \\
\hline 5 & $\begin{array}{l}\text { Algerian Electricity Transport Network } \\
\text { Management Company (SGTE) }\end{array}$ & $\begin{array}{c}\text { SONELGAZ subsidiary company is responsible for } \\
\text { electricity transmission. }\end{array}$ \\
\hline 6 & Electricity distribution companies & $\begin{array}{l}\text { SONELGAZ subsidiary company is responsible for the distribution of } \\
\text { electricity that comprises the western distribution company (SDO), the } \\
\text { eastern company (SDE), the Algiers distribution company (SDA) and } \\
\text { the central distribution company (SDC). }\end{array}$ \\
\hline 7 & Independent power producers & $\begin{array}{l}\text { The independent power producers in the country comprise companies } \\
\text { such as Shariket Kahraba Skikda (SKS), Shariket Kahraba Berrouaghia } \\
\text { (SKB), Shariket Kahraba Terga (SKT), Shariket Kahraba Koudiet } \\
\text { Eddraouche (SKD), and Shariket Kahraba Hadjret Ennouss (SKH). }\end{array}$ \\
\hline
\end{tabular}

\section{RE Program and Regulations}

\subsection{RE Programs}

Algeria relies heavily on its primary energy generation, which is natural gas, to meet its electricity demands. The country is committed to diversifying its energy mix due to declining oil and gas prices alongside environmental issues. In February 2011, the country launched the Renewable Energy Development and Energy Efficiency Program (PENREE) to introduce RE into the nation's energy mix. Initially, the program plant aims to provide $12 \mathrm{GW}$ of national RE installations and $10 \mathrm{GW}$ of RE export between 2011 to 2030. The goal of this program is to have $40 \%$ of the energy mix from RE by 2030 . The national RE program installation was planned in three stages. The first stage was the establishment of pilot projects from 2011 to 2013. Next, the development of additional projects to be commenced from 2014 to 2015. Finally, large scale development of RE projects will be completed from 2016 to 2020 . Meanwhile, the $10 \mathrm{GW}$ RE energy export is planned to be installed between 2021 to 2030 .

In February 2015, MEM announced the updated RE program. The primary goal of the updated program related to RE is to have $22 \mathrm{GW}$ of RE installation by 2030, contributing $27 \%$ to the energy mix [70]. The program comprises two stages of targets which are: $4395 \mathrm{MW}$ installation between the year 2015 to 2020 and a total 17,605 MW from 2021 to 2030. Figure 14 shows the target installations of RE based on technologies. However, in 2019, the government announced that they were going to relaunch PENREE to accelerate RE development in the country [71]. Hence, Algeria will be focusing more on solar energy development through the call for tenders in 2020. 


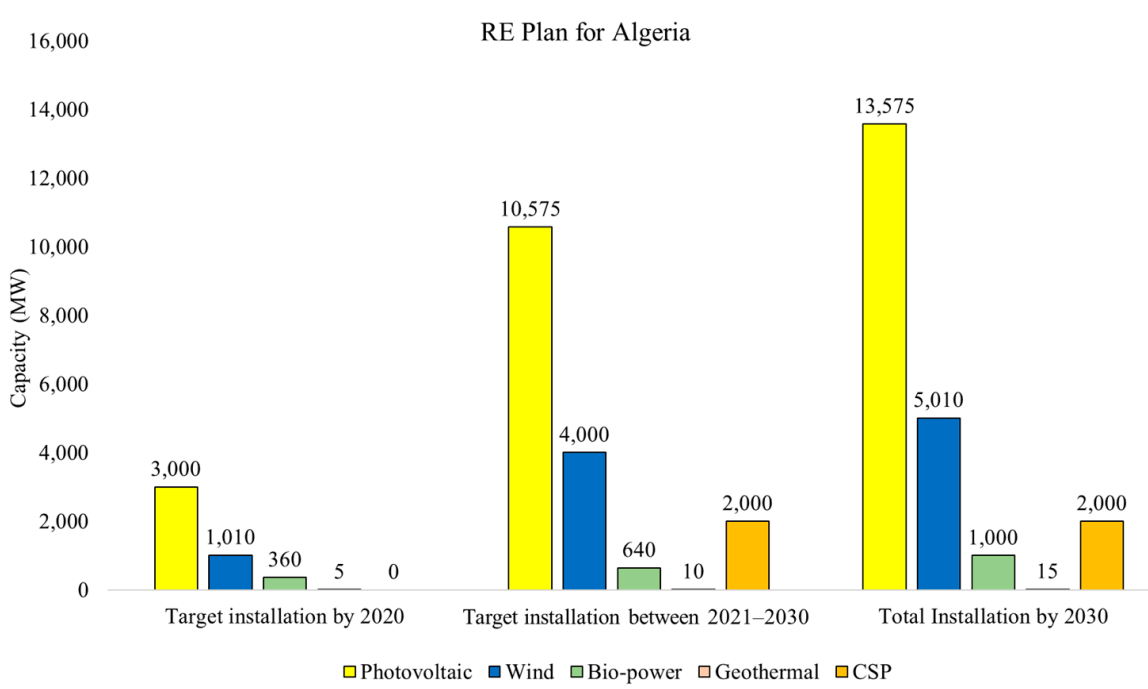

Figure 14. Algeria RE current and future generation plan.

\subsection{RE Regulations}

The primary law and orders related to the promotion and production of RE in Algeria are shown in Figure 15. Law No. 04-09 of 2004 allows Algeria to clearly define the RE goals for the country [10,72]. Law No. 09-09 of 2009 was launched to achieve these goals with a practical set of measures, such as the establishment of the National Fund for Renewable Energy (NFRE) and the allocation of $0.5 \%$ of oil royalties for the RE fund. Additionally, Law No. 11-11 in 2011 established the National Fund for Renewable Energies and Cogeneration (NFREC), where the NFRE was extended to include cogeneration activities alongside the increment of $1 \%$ of oil royalties for the RE fund $[10,72]$. Later, the incentives to increase RE generation were identified in the Executive Decree No. 13-218 of 2013. Thus, the government pledged to grant bonuses for the diversification of electricity from RE generation, alongside buying RE electricity produced by both public and private entities. Lastly, Executive Decree No. 17-98 and Executive Decree No. 17-204 were introduced in 2017, where RE generation projects need to be distributed through tenders and auctions $[10,72]$.

Law No. 02-01: Distribution of electricity and gas ensures the purchase of RE
Law No 09-09: Provide regulation for the creation NFRE and determine financial resources of $0.5 \%$ oil royalties for $\mathrm{RE}$
Executive decree No. 13-218: Setting incentive measures to promote RE such as bonuses and FiT
Law No. 14-10: The merger of the two special funds, The National Fund for Energy Management (FNME) and NFREC

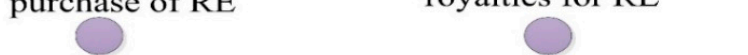

Aug 2004

Jul 2011
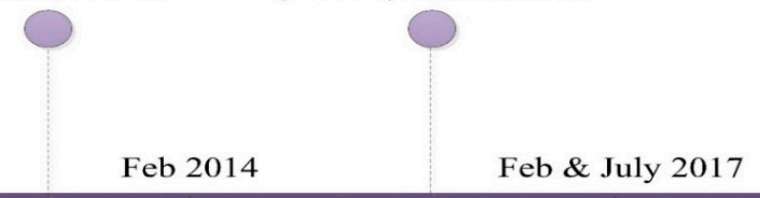

Feb 2002
Law No 04-09:
Promotion of RE for
sustainable
development

Dec 2009

Law No. 11-11: Establishment NFREC and determine financial resources of $1 \%$ oil royalties for $\mathrm{RE}$
Order of 2 Rabie Ethani 1435: Introduce new FiT for solar PV and wind
Dec 2014

Executive Decree No. 17-98 \& Executive Decree $N^{\circ}$ 17-204: Defines the legal procedures for tendering to produce $\mathrm{RE}$ and cogeneration, and their integration into the national electricity system.

Figure 15. Major laws and regulations related to RE in Algeria. 


\subsection{Financial Aids}

The development of new RE generation was contributed by the Algerian government through the NFREC. The fund primarily contributed via the $1 \%$ tax imposed for oil revenue, alongside energy consumption taxes. The goal of the fund is not just limited to financing feed-in tariffs under the power purchase agreement (PPA), but also to finance the development of new RE projects. Algeria is the first African country to introduce the feed-in tariff (FiT) scheme through Executive Decree No. No.04-92 of 2004, to boost RE development and diversity in their energy mix [73]. The RE technologies included in the FiT scheme are CSP, bio-power, solar PV, hydropower, and wind. Meanwhile, the Executive Decree No. 13-218 of 2013 provides administration of the FiT implementation, alongside bonuses in the percentage of the price per $\mathrm{kWh}$. Based on the executive decree, the bonuses for RE generation from solar PV and wind amount to $300 \%$ for CSP, $200 \%$ for bio-power and $100 \%$ for hydropower [73]. Moreover, there is also a financial aid bonus for a hybrid CSP and gas system that is based on the CSP contribution. The system, with a CSP capacity of $25 \%, 20 \%$ to $25 \%, 15 \%$ to $20 \%, 10 \%$ to $15 \%$ and $5 \%$ to $10 \%$ are granted bonuses of $200 \%$, $180 \%, 160 \%, 140 \%$ and $100 \%$, respectively. Additionally, the country launched a new tariff in 2014 that is valid for 20 years for solar PV and wind [74]. The FiT for RE in Algeria is summarized in Table 5.

Table 5. Feed-in tariffs (FiT) for RE in Algeria $[10,73,75]$.

\begin{tabular}{cccccc}
\hline Source & Contribution & \multicolumn{2}{c}{ FiT (DZD/kWh) } & \multicolumn{2}{c}{ FiT (USD/kWh) } \\
\hline \multirow{2}{*}{ PV } & & First 5 Years & $\mathbf{5}$ to 15 Years & First 5 Years & $\mathbf{5}$ to 15 Years \\
& $<5 \mathrm{MW}$ & 15.94 & $11.80-20.08$ & 0.12 & $0.089-0.15$ \\
\multirow{2}{*}{ Wind } & $>5 \mathrm{MW}$ & 12.75 & $9.44-16.06$ & 0.096 & $0.071-0.12$ \\
& $<5 \mathrm{MW}$ & 13.10 & $9.55-16.66$ & 0.098 & $0.072-0.13$ \\
& $>5 \mathrm{MW}$ & 10.48 & $7.64-13.33$ & 0.079 & $0.057-0.10$ \\
\hline
\end{tabular}

\subsection{RE Program Effectiveness Status}

Table 6 shows the target and achievement of Algeria RE installation up to early 2020. The installed RE capacity, as of early 2020, is significantly lower than the target [76]. The progress of PV and wind are far from the target capacity with $13.33 \%$ and $5 \%$, respectively. Meanwhile, there is no development for other RE generations, such as bio-power and geothermal.

Table 6. National RE program target installation and achievements.

\begin{tabular}{cccc}
\hline Source & Target in 2020 (MW) & Installed in 2020 (MW) & Achievement (\%) \\
\hline PV & 3000 & 400 & 13.33 \\
Wind & 1010 & 50 & 5 \\
Bio-power & 360 & 0 & 0 \\
Geothermal & 5 & 0 & 0 \\
CSP & - & 25 & - \\
\hline TOTAL & 4375 & 475 & 10.7 \\
\hline
\end{tabular}

\section{Renewable Energy Status}

\subsection{Solar}

The RE master plan in Algeria focuses on the development of solar energy, with a total of 13,500 MW solar PV generation planned for 2030. The RE installed in Algeria based on technology is shown in Figure 16. Most of the installed PV in the country is aimed at providing electricity to rural areas with difficulties in grid extension. Figure 17 shows the locations of all PV stations in the country, and the list of installed PV farms is listed in Table 7. 
Algeria's Renewable Energy Capacity

500

400

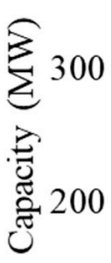

100

0

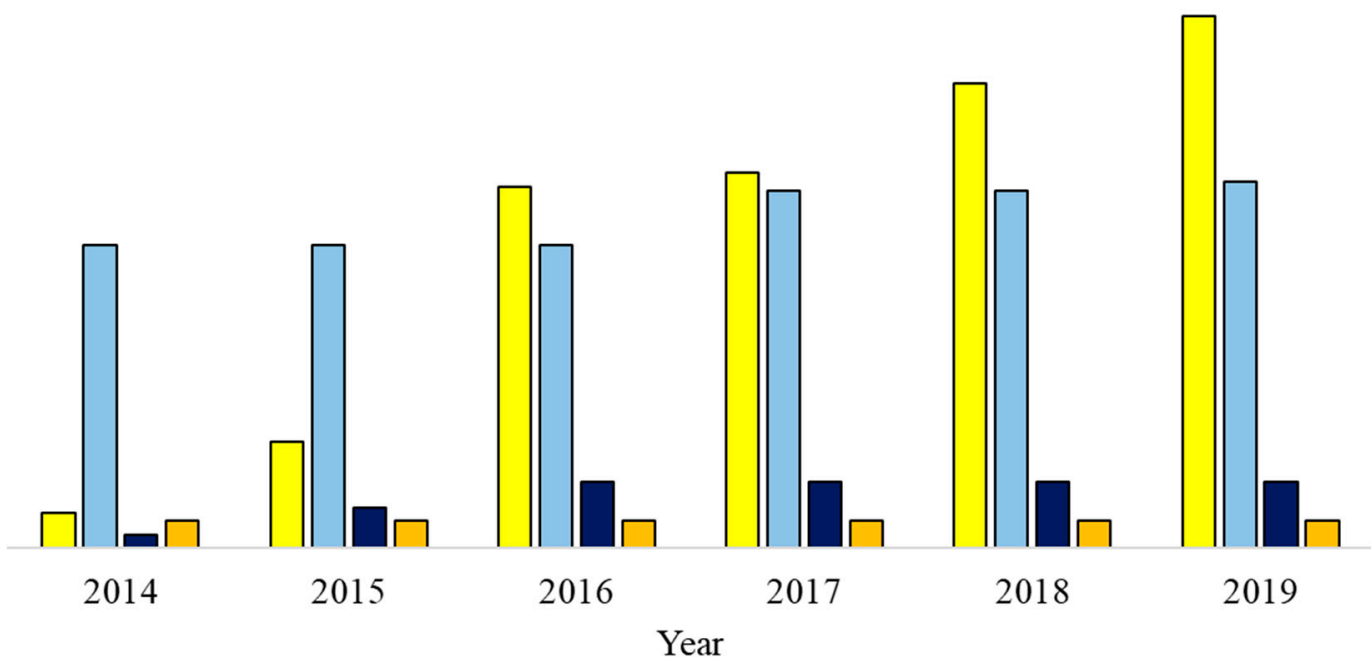

\section{$\square$ Solar PV $\square$ Hydro $\square$ Wind $\square$ CSP}

Figure 16. RE installed capacity in Algeria from 2014 to 2019.

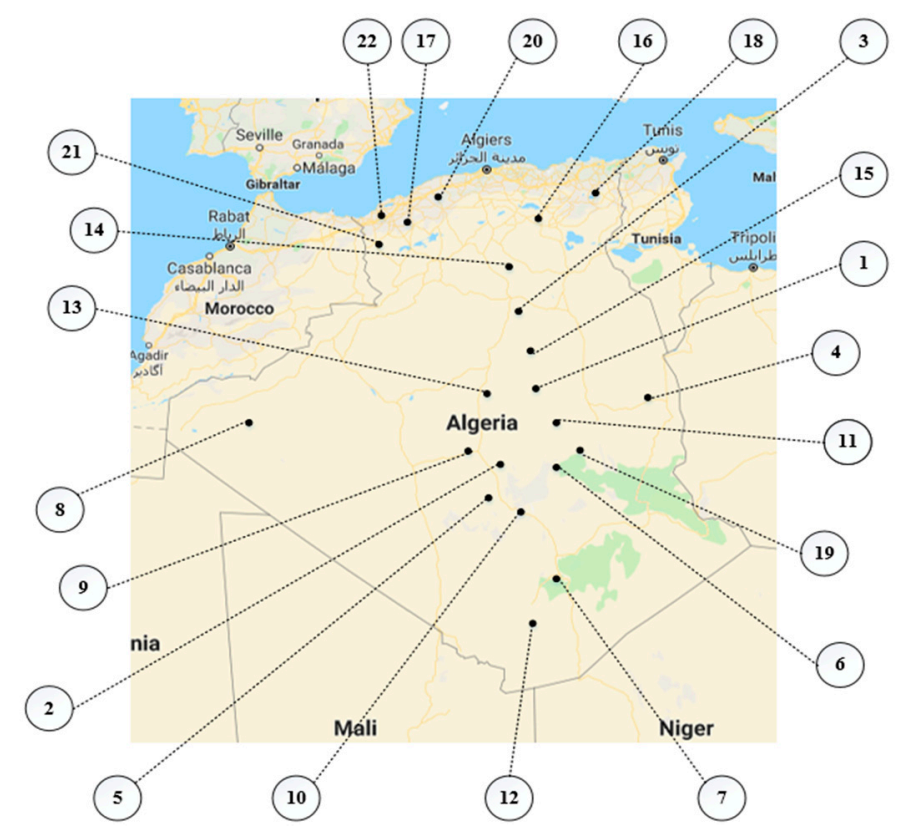

Figure 17. Locations of PV stations in Algeria. 
Table 7. Installed solar generation stations [6].

\begin{tabular}{cccc}
\hline & Station & Location & Capacity (MW) \\
\hline 1 & SPP1 & Hassi R'mel & 25 \\
2 & SPE & Adrar & 10 \\
3 & Ghardaïa & Ghardaïa & 11 \\
4 & Djanet & Illizi & 3 \\
5 & Adrar & Adrar & 20 \\
6 & Kabertene & Adrar & 13 \\
7 & Tamanrasset & Tamanrasset & 13 \\
8 & Tindouf & Tindouf & 9 \\
9 & Z.Kounta & Adrar & 6 \\
10 & Timimoun & Adrar & 9 \\
11 & Reggane & Adrar & 5 \\
12 & In-salah & Tamanrasset & 5 \\
13 & Aoulef & Adrar & 5 \\
14 & Ain EL-Lbel & Djelfa & 20 \\
15 & Khang & Lghouat & 20 \\
16 & Oued EL-Kebrit & Souk Ahras & 15 \\
17 & Sedrate Leghzal & Naama & 20 \\
18 & Ain EL-Melh & M'sila & 20 \\
19 & EL-Hadjira & Touggourt & 10 \\
20 & Ain Shouna & Saida & 30 \\
21 & E.B.S Chikh & El Bayadh & 24 \\
22 & Telga & Telemcene & 12 \\
\hline
\end{tabular}

Figure 18 shows the two PV power stations installed in Algeria.

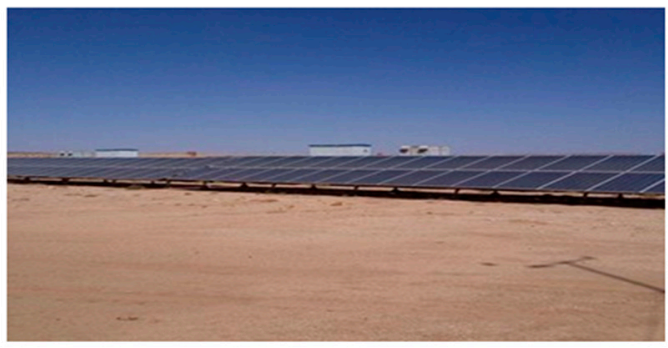

(a)

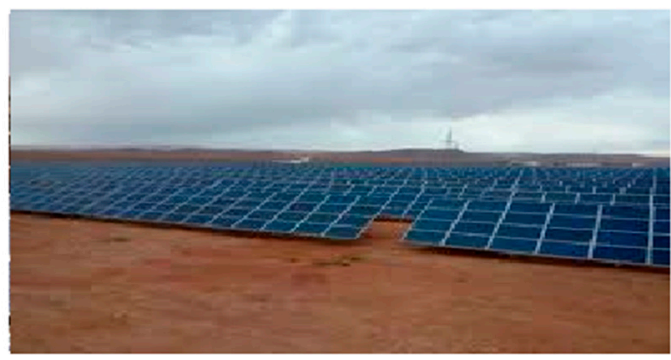

(b)

Figure 18. (a) PV farm in Tamanrasset. (b) PV farm in Djelfa.

The country's first solar plant was installed in 2011, and there were 22 plants availablewith a total capacity of $423 \mathrm{MW}$ - at the end of 2019, which is seven times lower than the target of $3000 \mathrm{MW}$ by 2021 [23]. According to the initial target, a total of $60 \mathrm{PV}$ generation plant projects were planned for the period 2011 to 2020.

In recent years, the country has relied on imported solar modules from countries such as France, Spain, and China, leading to high-cost solar projects. Therefore, the country has promoted domestic solar module manufacturing facilities. The government also supports the solar module manufacturing company through the requirement of local PV modules 
and systems in the tender for large solar projects. Hence, there have been several solar module factories developed in Algeria by companies such as Condor, ALPV, Aures Solaire, and ENIE to serve national solar projects. Table 8 lists PV factory locations in Algeria and their annual capacities. Condor established the country's first solar factory in Bordj Bou Arreridj, northern Algeria, in late 2013. The company also has a 51\% stake in the French-Algerian company, Aures Solaire, that has a 50 MW manufacturing facility in Sidi Bel Abbes, western Algeria, and a $30 \mathrm{MW}$ facility in Batna, eastern Algeria. The Algerian state-owned electronics company, ENIE, has a solar manufacturing facility with an annual capacity of $25 \mathrm{MW}$ in Sidi Bel Abbes, western Algeria. Additionally, the Algerian PV Company (ALPV) owned a PV production facility with an annual capacity of $12 \mathrm{MW}$ in Batna, eastern Algeria. Moreover, Miltech-the country's telecom company and also a renewable energy company - is currently building a solar module manufacturing facility with a $100 \mathrm{MW}$ annual capacity in Chelghoum El Aid, northeast Algeria, aimed to be completed by 2021 [77].

Table 8. PV factory locations in Algeria.

\begin{tabular}{cccc}
\hline Company & Capacity (MW) & Location & In Operation Since \\
\hline Condor & 130 & Bordj Bou Arreridj, Northern & 2013 \\
ALPV & 12 & Algeria & 2010 \\
Aures solaire & 50 & Batna, Eastern Algeria & 2016 \\
Aures solaire & 30 & Sidi Bel Abbes, Western & 2017 \\
ENIE & 25 & Algeria & 2016 \\
Milltech & 100 & Sidi Bel Abbes, Western & Algeria \\
& & Chelghoum El Aid, & 2020 (under \\
& & Northeast Algeria & development) \\
\hline
\end{tabular}

In 2018, the CREG launched the first solar tender for 150 MW PV capacity for deployment at five locations in the country. This tender has had limited success with only eight proposals for a total combined capacity of $90 \mathrm{MW}$, with only $50 \mathrm{MW}$ procured [23]. The $50 \mathrm{MW}$ winning project was awarded to Power Generation, owned by the Algerian company Condor. The successful project was awarded a 20-year PPA, where they will build and operate the plant. In early 2020, the country relaunched PENREE by opening another $150 \mathrm{MW}$ tender and seeking proposals from both foreign and local companies. These are part of the country's plan to achieve the 2000 MW target by the end of 2020 [78].

Algeria has also focused on the development of solar thermal energy, such as CSP, as a major source of RE, to cover $5 \%$ of the national energy mix by 2030 . Initially, six solar thermal plants are planned for the country by 2021. Algeria has one integrated solar combined cycle plant in Hassi R'mel, with a capacity of $25 \mathrm{MW}$ solar CSP and a $130 \mathrm{MW}$ combined cycle gas plant, as shown in Figure 19. 


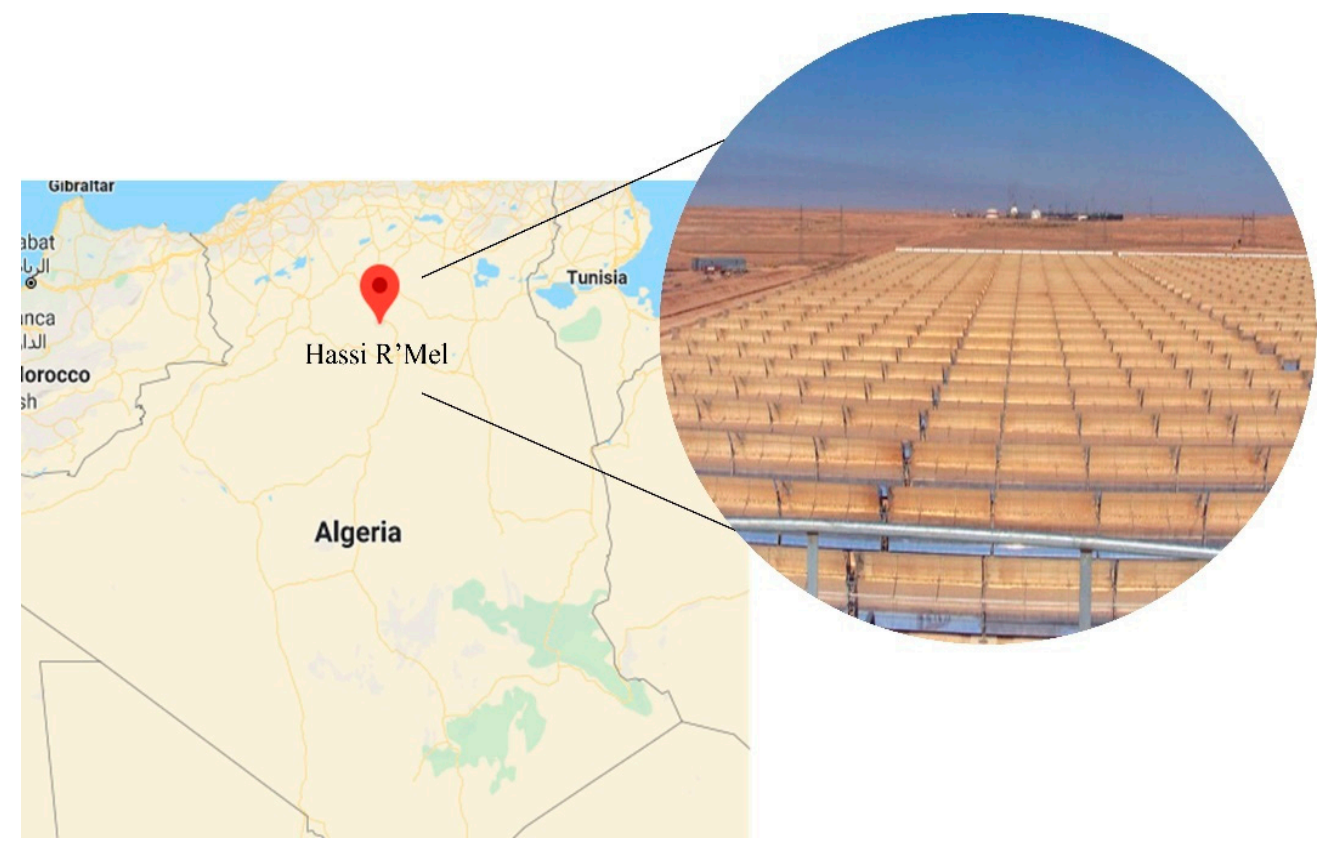

Figure 19. CSP Hassi R'mel station (Source: edited from Google Maps).

\subsection{Hydropower}

There are 13 hydropower plants in Algeria, with an annual generation of $389.4 \mathrm{GWh}$, which represents the third-largest energy mix in the country after natural gas and oil. The country's small hydropower system (below $10 \mathrm{MW}$ system) contributes $42 \mathrm{MW}$ to the total energy generation [79].

Most of the hydropower plants are in the northern regions of the country. Figure 20 shows the locations of hydropower plants in Algeria. Meanwhile, Table 9 shows the list of hydropower installed plants based on the MEM report. The hydropower capacity, based on the MEM report back in 2007, was 269 MW from a total of 13 hydropower stations [58]. Meanwhile, the hydropower generation capacity was reported to be $228 \mathrm{MW}$ from 2014 to 2016 and increased to 269 MW from 2017 till 2019, based on the Hydropower Status Reports by the International Hydropower Association (IHA) [24-29].

Table 9. Hydropower plants in Algeria.

\begin{tabular}{ccc}
\hline No & Station & Capacity (MW) \\
\hline 1 & Draguina (Bejaia) & 71.5 \\
2 & Ighil emda (Bejaia) & 24 \\
3 & Mansoria (Bejaia) & 100 \\
4 & Erraguene (Jijel) & 16 \\
5 & Souk el djemaa (Relizane) & 8.085 \\
6 & Tizi meden (Tizi ouzou) & 4.458 \\
7 & Ighzenchebel (Algiers) & 2.712 \\
8 & Ghrib (Ain defla) & 7 \\
9 & Gouriet (Bejaia) & 6.425 \\
10 & Bouhanifia (Mascar) & 5.700 \\
11 & Oued fodda (Chlef) & 15.6 \\
12 & Beni behdel (Tlemcen) & 3.5 \\
13 & Tessala (Algiers) & 4.228 \\
\hline
\end{tabular}




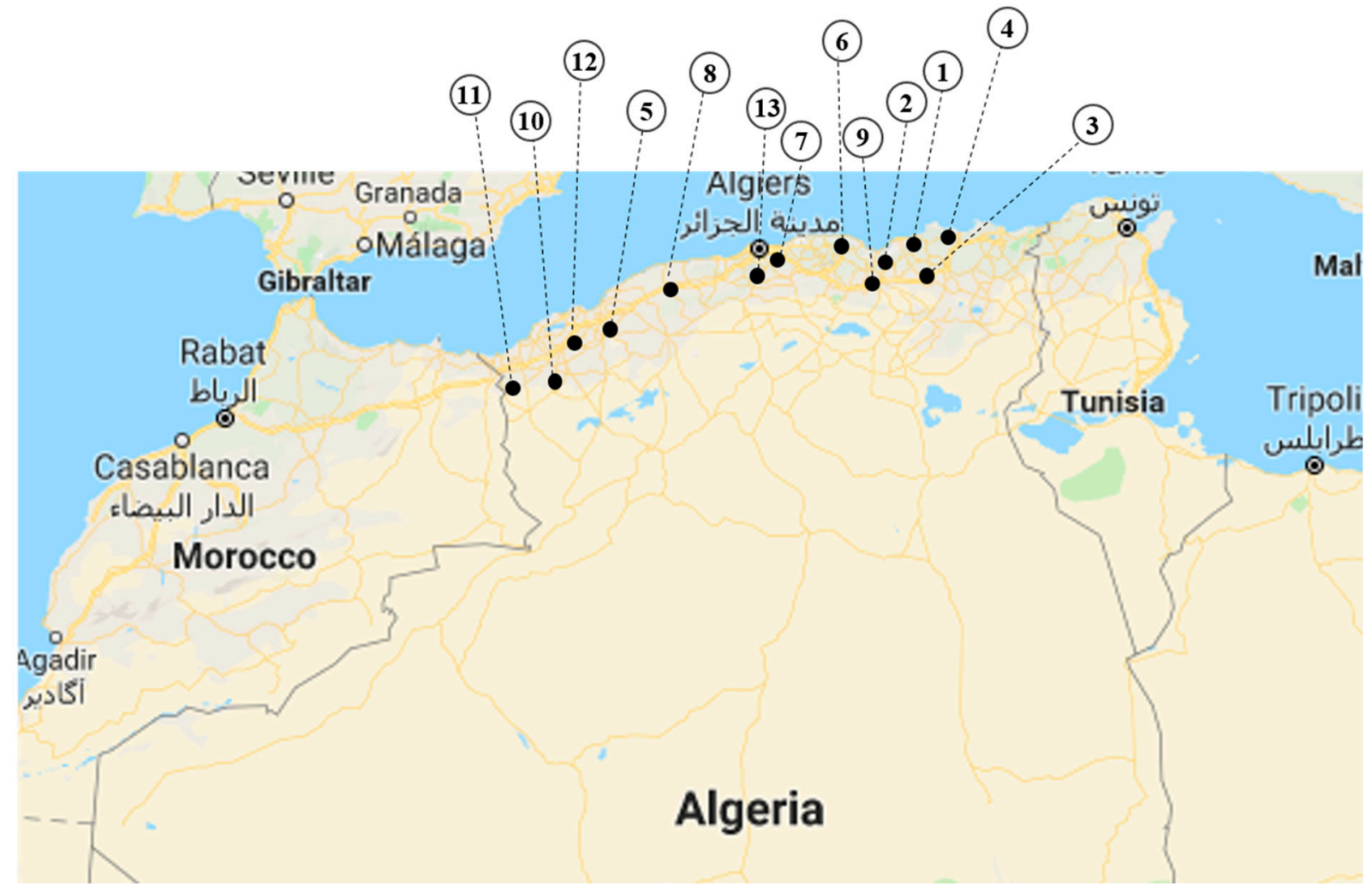

Figure 20. Locations of hydropower plants in Algeria.

Although the country has a hydropower capacity of up to $269 \mathrm{MW}$, the country started to cease the operation of all hydropower generation stations in phases starting from 2014 and devoting effort to dams for water and irrigation purposes due to water shortages [80,81]. Hence, the hydropower generation of the country dropped by $13 \%$ from 2007 to 2017, as shown in Figure 21.

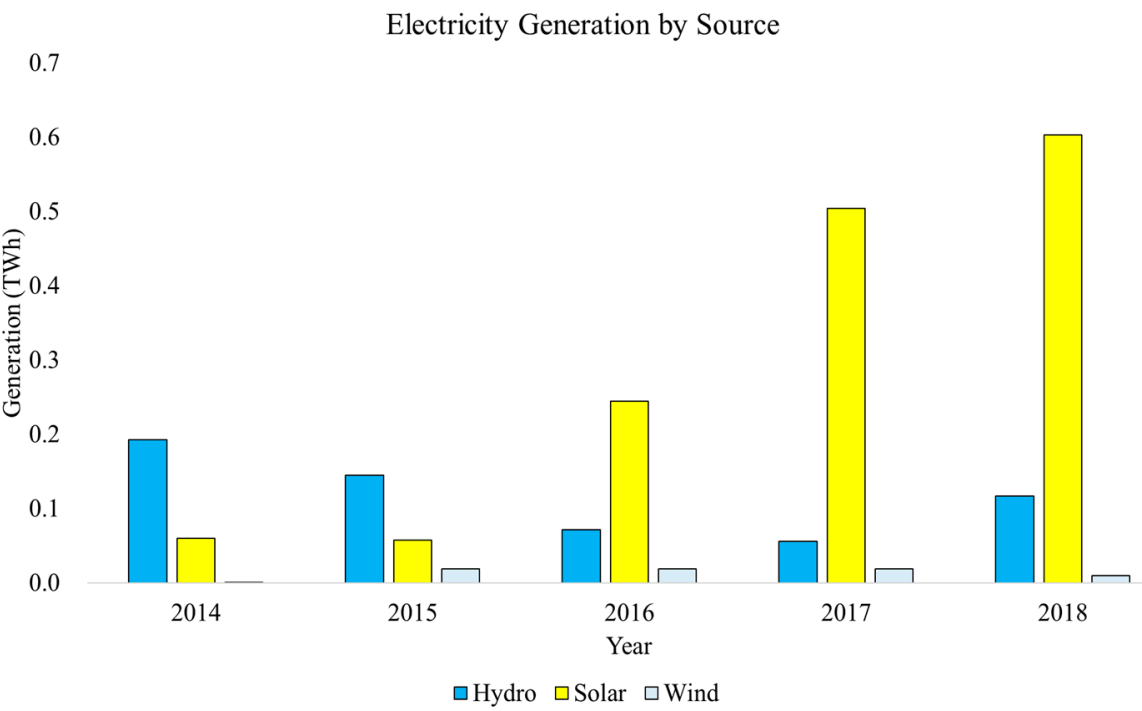

Figure 21. Algeria electricity generation by RE from 2014 to 2018.

\subsection{Wind}

The first and only wind turbine farm in Algeria was installed in 2014 at Kabertene Adrar in the southern region of the country with a generation capacity of 10 MW [10,60]. The onshore wind farm—owned and operated by Sonelgaz-comprises 12 units of $850 \mathrm{~kW}$ 
turbines. Figure 22 shows the wind farm located in Adrar. Initially, there were seven wind generation plants planned for completion by 2021 . However, only one plant has been developed and is operational. As illustrated in Figure 17, the wind energy generation dropped by $47.4 \%$ from $19 \mathrm{GWh}$ in 2017 to $10 \mathrm{GWh}$ in 2018. Although the wind generation target in the country is $3000 \mathrm{MW}$ by 2030 , no news or information has been made available by the government or RE companies as regards wind power projects in the near future. The slower progress of wind generation compared to solar may be due to the moderate wind speed, less profitability, and high associated maintenance costs [82]. Moreover, the country also has less experience in wind generation, with less precise wind maps available [82].

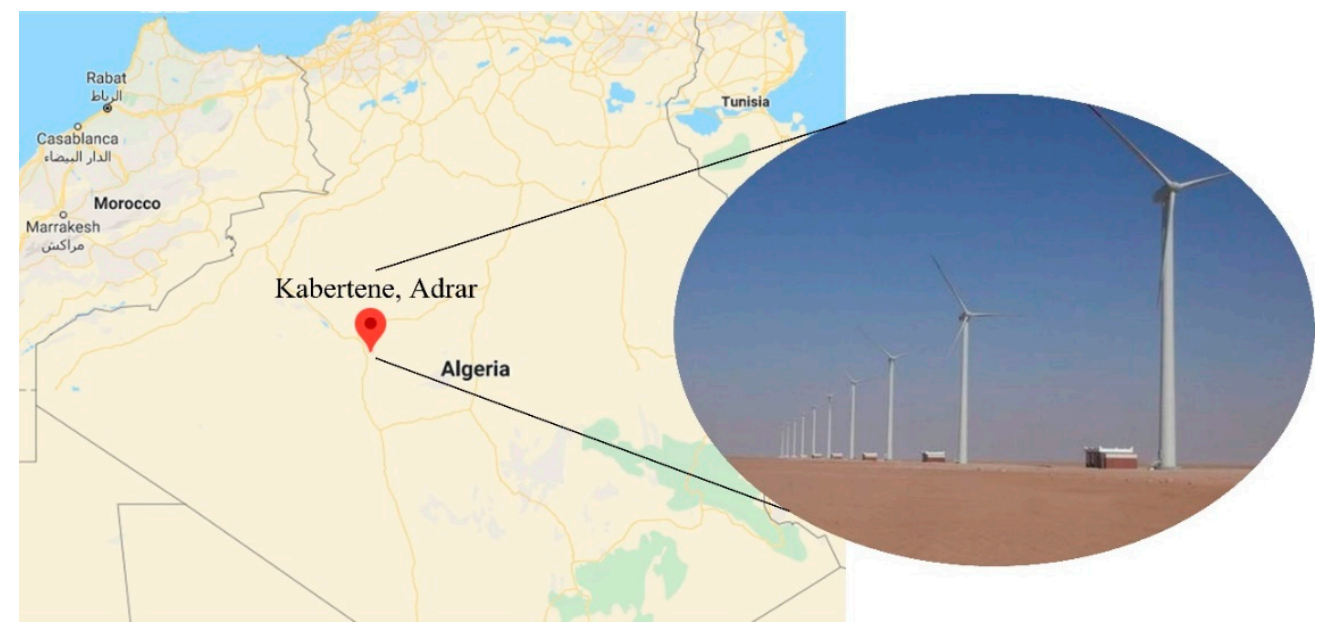

Figure 22. The $10 \mathrm{MW}$ wind power farm in Kabertene, Adrar.

\subsection{Geothermal}

The CDER established a geothermal center located in Saida (Sidi Aissa) for the research and development of geothermal power generation. The country has a geothermal generation target of only $15 \mathrm{MW}$ by 2030. Currently, there are no planned projects in the pipeline for geothermal generation in the country.

\subsection{Bio-Power}

The CDER established a bio-power research and development facility in the Ouled Fayet landfill. The target for Bio-power generation in the country is $1 \mathrm{GW}$ by 2030 . Currently, there is no bio-power generation in the country. In 2020, the government stated that the country would join the German Deserted project for RE supply that includes solar, wind, hydro, and biomass in Europe and the North African region [83].

\section{Social, Economic and Environmental}

The RE projects aimed to improve the country's social, economic, and environmental development. The RE has immense potential for contributing to the creation of new jobs, education, agricultural improvements, municipal water supplies, and low carbon development.

The PENREE initial goal is not only limited to RE development and energy security, but the plan also aims to create new jobs in the country. The plan includes the creation of 100,000 for national RE production and 100,000 positions for RE energy export [84]. In 2020, the planned large solar power projects with up to 4 GW generation capacity are expected to create job opportunities for 56,000 people during the construction phase and 2000 more jobs during operation [85]. According to [86], the 20 year solar PV and wind project, considering construction, installation, and manufacturing, alongside operation and maintenance, will create an average of 9.57 jobs/MW and 0.93 jobs/MW, respectively. Hence, there is only an estimated 3800 jobs currently available in the Algerian RE sector, compared to 58,000 jobs that are planned to be made available by 2021 . 
In 2011, Algeria introduced a solar water heating program called ALSOL administered by the National Agency for Promotion and Rationalization of Energy (APRUE). The ALSOL program was modeled based on the Tunisian solar water heating program called PROSOL that has been successfully implemented since 2005. The pilot phase consisted of a $45 \%$ subsidy for 400 residential systems with 200 L storage tanks. The installation license for the 400 systems was distributed to 15 local companies. The systems were imported from Tunisia and France due to no local manufacturers being available in the country. In mid2011, APRUE announced the continuation of ALSOL for 2000 residential homes with a similar subsidy. As of 2020, there has been no new update related to this program, and no new programs related to solar water heating have been announced by the government since then.

As for the education sector, the government has recently announced the development of an executive decree on the establishment of an educational institution to train RE and sustainable development professionals [87]. The graduated professionals from this program will support the job needs for the 22 GW RE plan by 2030. Moreover, Telemcen University in Algeria collaborated with the CDER for the development of RE short courses and training [88]. The Solar Development Unit (UDES) and Silicium Technology Development Unit (UDTS) also have several collaborative programs with higher education institutions in the country [89].

The $\mathrm{CO}_{2}$ emissions in the country are greatly influenced by the power generation from both oil and gas. Algeria ranked 83 at the Environmental Performance Index (EPI) out of 180 countries in 2018 [1]. Algeria committed to the Intended Nationally Determined Contribution (INDC) and agreed to reduce its greenhouse gas emissions by 7\% by 2030 . This target is supported by the nation RE program that aims to contribute $27 \%$ to the energy mix from solar and wind sources by 2030. Figure 23 illustrates the $\mathrm{CO}_{2}$ emission trend in the country. The $\mathrm{CO}_{2}$ emitted in the country was 135.5 million tons in 2018 , which is $6 \%$ higher than in 2017 [40]. The $\mathrm{CO}_{2}$ trend has been increasing since the past decade, with an average growth of $4.1 \%$ due to the increasing load demand leading to increased power generation from fossil fuel resources [12].

\section{$\mathrm{CO}_{2}$ Emissions}

$$
160
$$

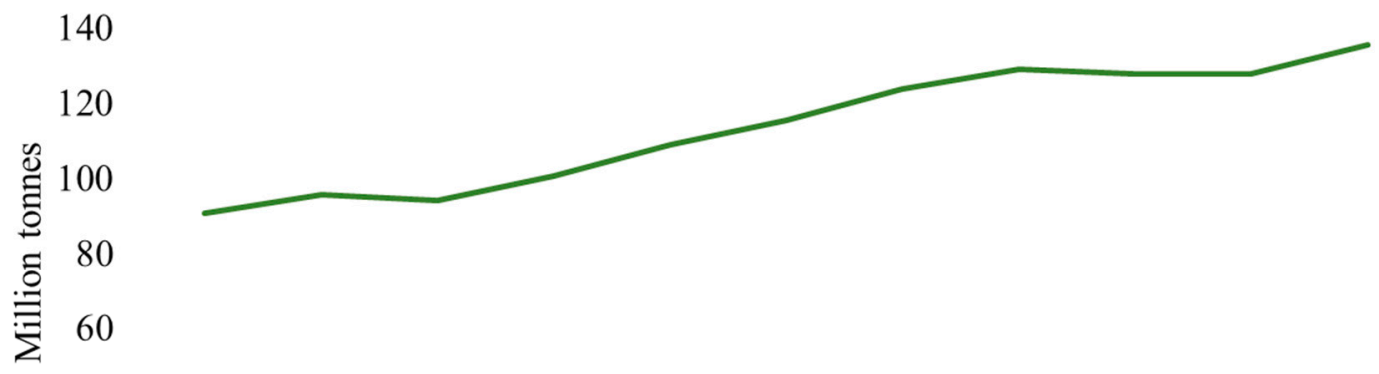

Figure 23. Algeria $\mathrm{CO}_{2}$ emission trend from 2008 to 2018. 


\section{Conclusions}

This paper provides a critical review of the current energy situation in Algeria, alongside discussion of RE resource availability and development status. RE has proven to be a feasible solution to the current energy crisis in the country due to the fluctuation of fuel prices in the international market. Currently, the country relies heavily on its hydrocarbon sector, such as oil and gas, which contribute to $99.47 \%$ of its energy mix. Moreover, the country load demand has experienced a growth of $7 \%$ over the past decade, leading to higher levels of energy consumption and high carbon emissions. Several vital laws, regulations, and programs have been introduced to increase the RE generation in the country. The goal of the national RE program, PENREE, that was introduced in 2011, is to have $22 \mathrm{GW}$ of RE generation, contributing to $27 \%$ of the country's energy mix by 2030 . The RE program was updated in 2015 and 2019. This program primarily targets to increase solar energy generation in the country. The plan is to have 13,575 MW of solar energy, $2000 \mathrm{MW}$ CSP, $5010 \mathrm{MW}$ of wind energy, 1.00 MW bio-power, and $15 \mathrm{MW}$ geothermal generation by 2030. Currently, there are only $22 \mathrm{PV}$ plants available in the country with a total generation power of $400 \mathrm{MW}$, one turbine plant with a total generation power of $10 \mathrm{MW}$, and one CSP plant with a total capacity of $25 \mathrm{MW}$. There are 11 hydropower plants in the country with an annual generation of 389.4 GWh. However, in 2014, the government decided to devote hydropower dams for water and irrigation purposes, leading to reduced power generation. The country currently has no available geothermal or bio-power generation capacity. To significantly increase RE development, the government has released tender for a $150 \mathrm{MW}$ large solar plant project to be commenced 2020.

Moreover, a new PV manufacturing factory by Miltech will be developed by 2021 with a $100 \mathrm{MW}$ annual capacity, to add to the current five solar factories with a total capacity of 247 MW. RE development was anticipated to contribute benefits to the country's society, economy, and environment. Currently, the RE projects have only created 3800 new jobs, with a target of 58,00 jobs by 2021. $\mathrm{CO}_{2}$ emissions are increasing, with $4.1 \%$ growth since the last decade due to an increase in energy demand with no significant emission reductions from RE generation. Additionally, the country also has a solar water heating program called ANSOL, which was introduced in 2011 to subsidize $45 \%$ of the installation cost for 400 residential houses. The country also aims to develop educational institutions to support the needs of RE professionals. The CDER, alongside other RE entities in the country, has collaborated with local universities for short courses and training.

Author Contributions: Y.Z.: conceptualization, methodology, data curation, investigation, visualization, writing - reviewing and editing. M.R.B.K.: conceptualization, data curation, investigation, validation, methodology, visualization, writing - reviewing and editing, original draft preparation, supervision. I.A.: writing-reviewing and editing. S.M.: reviewing and supervision. M.A.: reviewing and supervision. All authors have read and agreed to the published version of the manuscript.

Funding: The authors would like to acknowledge the financial support received from Taif University Researchers Supporting Project Number (TURSP-2020/146), Taif University, Taif, Saudi Arabia and the Ministry of Higher Education, Malaysia for the financial support under the Long-Term Research Grant Scheme (LRGS): LRGS/1/2019/UKM-UM/01/6/3.

Institutional Review Board Statement: Not Applicable.

Informed Consent Statement: Not Applicable.

Data Availability Statement: Not Applicable.

Conflicts of Interest: The authors declare no conflict of interest. 


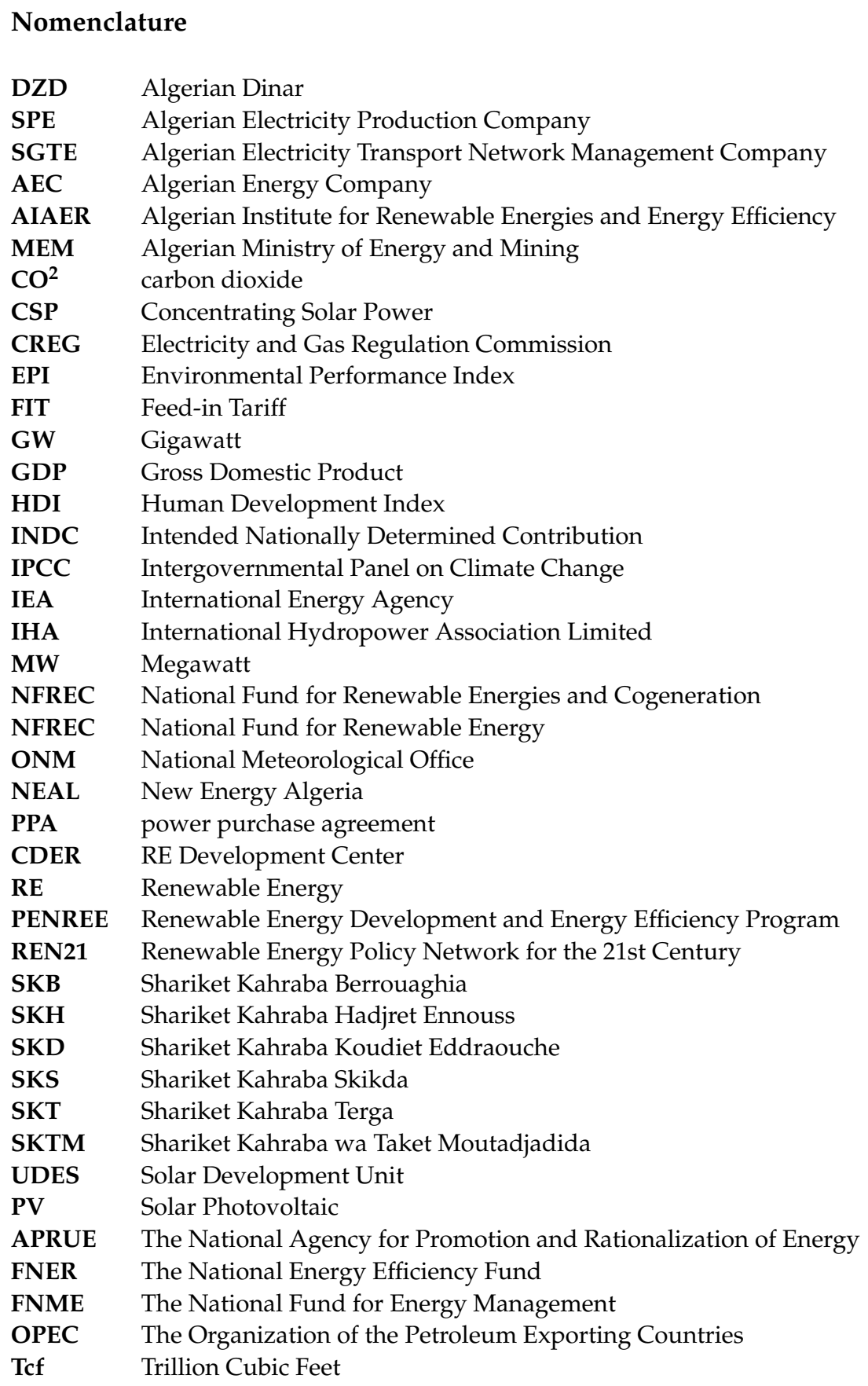

\section{References}

1. REN21. 2020 Renewables 2020 Global Status Report; REN21 Secretariat: Paris, France, 2020. Available online: http:/ /www.ren21.net/ (accessed on 20 May 2020).

2. IEA. World Energy Outlook 2019; IEA: Paris, France, 2019.

3. Intergovernmental Panel on Climate Change. Global Warming Report. 2018, pp. 10-30. Available online: http://www.ipcc.ch/ (accessed on 20 May 2020).

4. Gadonneix, P.; Sambo, A.; Guobao, Z.; Kim, Y.D.; Teyssen, J.; Lleras, J.A.V. World Energy Issues Monitor 2020. World Energy Counc. 2020. Available online: https:/ / www.worldenergy.org/ (accessed on 20 May 2020).

5. Lakhdar, H.M.; Rime, B.; Bruno, C. Massive integration of renewable energies in the Algerian electricity system: Integration factors and evaluation methodology. In Proceedings of the 2019 Algerian Large Electrical Network Conference (CAGRE), Algiers, Algeria, 26-28 February 2019; pp. 1-6.

6. Stambouli, A.B.; Khiat, Z.; Flazi, S.; Kitamura, Y. A review on the renewable energy development in Algeria: Current perspective, energy scenario and sustainability issues. Renew. Sustain. Energy Rev. 2012, 16, 4445-4460. [CrossRef] 
7. Stambouli, A.B. Promotion of renewable energies in Algeria: Strategies and perspectives. Renew. Sustain. Energy Rev. 2011, 15, 1169-1181. [CrossRef]

8. Bélaïd, F.; Youssef, M. Environmental degradation, renewable and non-renewable electricity consumption, and economic growth: Assessing the evidence from Algeria. Energy Policy 2017, 102, 277-287. [CrossRef]

9. Bouraiou, A.; Necaibia, A.; Boutasseta, N.; Mekhilef, S.; Dabou, R.; Ziane, A.; Sahouane, N.; Attoui, I.; Mostefaoui, M.; Touaba, O. Status of renewable energy potential and utilization in Algeria. J. Clean. Prod. 2020, 246, 119011. [CrossRef]

10. Bouznit, M.; Pablo-Romero, M.P.; Sánchez-Braza, A. Measures to Promote Renewable Energy for Electricity Generation in Algeria. Sustainability 2020, 12, 1468. [CrossRef]

11. U.S. Energy Information Administration. International Energy Outlook 2019 with Projections to 2050; 2019. Available online: www.eia.gov (accessed on 20 May 2020).

12. Dudley, B. BP Statistical Review of World Energy 2019; BP Stat Rev: London, UK, 2019.

13. Paris: REN21 Secretariat. REN21.2015 Renewables 2015 Global Status Report; 2015. Available online: http://www.ren21.net/ (accessed on 20 May 2020).

14. Paris: REN21 Secretariat. REN21.2016 Renewables 2016 Global Status Report; 2016. Available online: http://www.ren21.net/ (accessed on 20 May 2020).

15. Paris: REN21 Secretariat. REN21.2017 Renewables 2017 Global Status Report; 2017; pp. 1-307. Available online: http:/ /www.ren21. net/ (accessed on 20 May 2020). [CrossRef]

16. Paris: REN21 Secretariat. REN21.2018 Renewables 2018 Global Status Report; 2018. Available online: http://www.ren21.net/ (accessed on 20 May 2020).

17. Paris: REN21 Secretariat. REN21.2019 Renewables 2019 Global Status Report; 2019. Available online: http://www.ren21.net/ (accessed on 20 May 2020).

18. Gadonneix, P.; Sambo, A.; Guobao, Z.; Kim, Y.D.; Teyssen, J.; Lleras, J.A.V. World Energy Issues Monitor 2015. World Energy Counc. 2015. Available online: https:/ / www.worldenergy.org/ (accessed on 20 May 2020).

19. Gadonneix, P.; Sambo, A.; Guobao, Z.; Kim, Y.D.; Teyssen, J.; Lleras, J.A.V. World Energy Issues Monitor 2016. World Energy Counc. 2016. Available online: https:/ / www.worldenergy.org/ (accessed on 20 May 2020).

20. Gadonneix, P.; Sambo, A.; Guobao, Z.; Kim, Y.D.; Teyssen, J.; Lleras, J.A.V. World Energy Issues Monitor 2017. World Energy Counc. 2017. Available online: https://www.worldenergy.org/ (accessed on 20 May 2020).

21. Gadonneix, P.; Sambo, A.; Guobao, Z.; Kim, Y.D.; Teyssen, J.; Lleras, J.A.V. World Energy Issues Monitor 2018. World Energy Counc. 2018. Available online: https:/ / www.worldenergy.org/ (accessed on 20 May 2020).

22. Gadonneix, P.; Sambo, A.; Guobao, Z.; Kim, Y.D.; Teyssen, J.; Lleras, J.A.V. World Energy Issues Monitor 2019. World Energy Counc. 2019. Available online: https:/ / www.worldenergy.org/ (accessed on 20 May 2020).

23. Africa Energy Series. Algeria Special Report; 2020. Available online: www.africaoilandpower.com/ (accessed on 20 May 2020).

24. International Hydropower Association. Hydropower Status Report 2015; Int Hydropower Assoc: London, UK, 2015.

25. International Hydropower Association. Hydropower Status Report 2016; Int Hydropower Assoc: London, UK, 2016.

26. International Hydropower Association. Hydropower Status Report 2017; Int Hydropower Assoc: London, UK, 2017.

27. International Hydropower Association. Hydropower Status Report 2018; Int Hydropower Assoc: London, UK, 2018.

28. International Hydropower Association. Hydropower Status Report 2020; Int Hydropower Assoc: London, UK, 2020.

29. International Hydropower Association. Hydropower Status Report 2019; 2019. Available online: https://www.hydropower.org/ (accessed on 20 May 2020).

30. Ministère de l'énergie et des Mines; Société du Groupe Sonelgaz. Programme des Energies Renouvelables et de L'efficacité Energétique; 2011. Available online: https:/ /www.energy.gov.dz/ (accessed on 20 May 2020).

31. Ministère de l'énergie. Energie. 2020. Available online: https:/ / www.energy.gov.dz/ (accessed on 26 May 2020).

32. Shariket Kahraba wa Taket Moutadjadida (SKTM). Programme National des Energies Renouvelables 2015-2030; 2017. Available online: https: / /www.cder.dz/ (accessed on 20 May 2020).

33. Administration USEI. Country Analysis Executive Summary: Iran; 2019; pp. 1-6. Available online: https://www.eia.gov/ international/content/analysis/countries_long/Iran/pdf/iran_exe.pdf (accessed on 12 June 2020).

34. Bilgili, M.; Bilirgen, H.; Ozbek, A.; Ekinci, F.; Demirdelen, T. The role of hydropower installations for sustainable energy development in Turkey and the world. Renew. Energy 2018, 126, 755-764. [CrossRef]

35. Khan, M.R.B.; Jidin, R.; Pasupuleti, J.; Shaaya, S.A. Micro-hydropower potential assessment and generation volatility due to seasonal climate. In Proceedings of the 2014 IEEE International Conference on Power and Energy (PECon), Kuching, Malaysia, 1-3 December 2014; pp. 371-376. [CrossRef]

36. Khan, M.R.B.; Pasupuleti, J.; Jidin, R. Load frequency control for mini-hydropower system: A new approach based on self-tuning fuzzy proportional-derivative scheme. Sustain. Energy Technol. Assess. 2018, 30, 253-262. [CrossRef]

37. Zimny, J.; Michalak, P.; Bielik, S.; Szczotka, K. Directions in development of hydropower in the world, in Europe and Poland in the period 1995-2011. Renew. Sustain. Energy Rev. 2013, 21, 117-130. [CrossRef]

38. Meriem, B. Renewable Energy in Algeria Reality and. J. Inf. Syst. Technol. Manag. 2018, 3, 1-19.

39. International Energy Agency (IEA). Stat Data Brows; 2019. Available online: https://www.iea.org/data-and-statistics (accessed on 12 June 2020). 
40. International Renewable Energy Agency (IRENA). Global Renewables Outlook; 2020. Available online: https:/ /www.irena.org/ (accessed on 26 May 2020).

41. International Renewable Energy Agency (IRENA). Renewable Capacity Highlights; 2020. Available online: https://www.irena.org/ (accessed on 26 May 2020).

42. Souhila, M. The Economic Impact of Renewable Energy Sources in Algeria and Its Future Prospects. 2018. Available online: https: / / www.cder.dz/ (accessed on 26 May 2020).

43. Kumari, W.G.P.; Ranjith, P.G. Sustainable development of enhanced geothermal systems based on geotechnical research-A review. Earth Sci. Rev. 2019, 102955. [CrossRef]

44. Lu, S.-M. A global review of enhanced geothermal system (EGS). Renew. Sustain. Energy Rev. 2018, 81, 2902-2921. [CrossRef]

45. Abed, F.M.; Al-Douri, Y.; Al-Shahery, G.M. Review on the energy and renewable energy status in Iraq: The outlooks. Renew. Sustain. Energy Rev. 2014, 39, 816-827. [CrossRef]

46. Wilberforce, T.; El Hassan, Z.; Durrant, A.; Thompson, J.; Soudan, B.; Olabi, A. Overview of ocean power technology. Energy 2019, 175, 165-181. [CrossRef]

47. United States Central Intelligence Agency. The World Factbook 2018, Algeria; World Puplication Factb: 2018. Available online: https: / / www.cia.gov/ (accessed on 12 June 2020).

48. Entelis, J.P. Algeria: The Revolution Institutionalized; Routledge: Abingdon, UK, 2016. Available online: https:/ /www.routledge. com/Algeria-The-Revolution-Institutionalized/Entelis/p/book/9781138951136 (accessed on 12 June 2020).

49. Administration USEI. Technically Recoverable Shale Oil and Shale Gas Resources. 2013. Available online: Https: / /WwwEiaGov/ Analysis/Studies/Worldshalegas/Pdf/OverviewPdf (accessed on 20 May 2020).

50. Organization of Petroleum Exporting Countries (OPEC). Online Annual Statistical Bulletin 2017; 2017. Available online: https: / / www.opec.org/opec_web/flipbook/ASB2017/ASB2017/assets/common/downloads/ASB2017_13062017.pdf (accessed on 26 May 2020).

51. World Energy Council. Unconventional Gas a Global Phenomenon. World Energy Resour. 2016. Available online: https: / / www.worldenergy.org/ (accessed on 26 May 2020).

52. Ministère de l'énegie. Energies Nouvelles, Renouvelables et Maitrise de l'Energie. Ministère l'énegie; 2016; pp. 1-25. Available online: https: / / www.energy.gov.dz/?rubrique=energies-nouvelles-renouvelables-et-maitrise-de-lrenergie (accessed on 12 June 2020).

53. creg.dz. Commission for Regulation of Electricity and Gas. Program Indicative of the Requirements for Means of Production of Electricity (2008-2017). Available online: https:/ / creg.dz/ (accessed on 12 June 2020).

54. SPE (La Société Algéienne de Production de l'Eléctricité) Plan de Developpement 2018. Available online: https: / /www.spe.dz/ index.php/fr/ (accessed on 12 June 2020).

55. Himri, Y.; Malik, A.S.; Stambouli, A.B.; Himri, S.; Draoui, B. Review and use of the Algerian renewable energy for sustainable development. Renew. Sustain. Energy Rev. 2009, 13, 1584-1591. [CrossRef]

56. SONALGAZ. The National Balance of Electricity and Gas 2015; 2015; Volume 15. Available online: https://www.sonelgaz.dz/en/ home (accessed on 12 June 2020).

57. Ministère de l'énergie et des Mines. Guide des Energies Renouvelables 2007. Available online: https://www.energy.gov.dz/?article= contact (accessed on 26 May 2020).

58. Stambouli, A.B.; Koinuma, H. A primary study on a long-term vision and strategy for the realisation and the development of the Sahara Solar Breeder project in Algeria. Renew. Sustain. Energy Rev. 2012, 16, 591-598. [CrossRef]

59. Himri, Y.; Merzouk, M.; Merzouk, N.K.; Himri, S. Potential and economic feasibility of wind energy in south West region of Algeria. Sustain. Energy Technol. Assess. 2020, 38, 100643. [CrossRef]

60. Abdeslame, D.; Merzouk, N.K.; Mekhtoub, S.; Abbas, M.; Dehmas, M. Estimation of power generation capacities of a wind farms installed in windy sites in Algerian high plateaus. Renew. Energy 2017, 103, 630-640. [CrossRef]

61. Nedjari, H.; Haddouche, S.K.; Balehouane, A.; Guerri, O. Optimal windy sites in Algeria: Potential and perspectives. Energy 2018, 147, 1240-1255. [CrossRef]

62. Wang, L.; Kerrouche, K.D.E.; Mezouar, A.; Bossche, A.V.D.; Draou, A.; Boumediene, L. Feasibility Study of Wind Farm GridConnected Project in Algeria under Grid Fault Conditions Using D-Facts Devices. Appl. Sci. 2018, 8, 2250. [CrossRef]

63. Kedaid, F.Z. Database on the geothermal resources of Algeria. Geothermics 2007, 36, 265-275. [CrossRef]

64. Saibi, H. Geothermal resources in Algeria. Renew. Sustain. Energy Rev. 2009, 13, 2544-2552. [CrossRef]

65. Ouali, A.A.; Issaadi, A.; Maizi, D.; Ayadi, A.; Bouhdjar, A. Geothermal potential in the Ouarsenis-Biban-Kabylie (North Central Algeria): Hot spring catalogue. Arab. J. Geosci. 2019, 12, 741. [CrossRef]

66. Akbi, A.; Saber, M.; Aziza, M.; Yassaa, N. An overview of sustainable bioenergy potential in Algeria. Renew. Sustain. Energy Rev. 2017, 72, 240-245. [CrossRef]

67. Eddine, B.T.; Salah, M.M. Solid waste as renewable source of energy: Current and future possibility in Algeria. Int. J. Energy Environ. Eng. 2012, 3, 17. [CrossRef]

68. Energypedia. Algeria Energy Situation. 2013. Available online: https://energypedia.info/wiki/Algeria_Energy_Situation (accessed on 27 May 2020).

69. Enerdata. Algeria Adopts Renewable Energy Development Plan. 2015. Available online: https://www.enerdata.net/ publications / daily-energy-news/algeria-adopts-renewable-energy-development-plan.html (accessed on 5 June 2020). 
70. Jean Marie Takouleu. ALGERIA: State Relaunches Renewable Energy Programme to Save Gas. Afrik 21. 2019. Available online: https:/ / www.afrik21.africa/ (accessed on 11 June 2020).

71. IBP USA. Algeria Investment, Trade Laws and Regulations Handbook Volume 1 Strategic Information and Regulations; 2011. Available online: https://books.google.com.my/books/about/Algeria_Investment_Trade_Laws_and_Regula.html?id=D22yDwAAQBAJ\& redir_esc=y (accessed on 12 June 2020).

72. Gipe, P. Algerian Feed-in Tariff Decree 2004. 2009. Available online: http:/ / www.wind-works.org/ (accessed on 7 June 2020).

73. Michelle, D.; Davies, C. MENA: Algeria's Publication of Draft PPA for Solar PV and Wind 2015. Available online: https: //www.lexology.com/ (accessed on 7 June 2020).

74. Newly Updated Renewable Energy Program in Algeria. Jones Day Publ. 2015. Available online: https://www.jonesday.com/en/ insights /2015/04/newly-updated-renewable-energy-program-in-algeria (accessed on 7 June 2020).

75. Rubino, A.; Öztürk, I.; Lenzi, V.; Campi, M.T.C. Regulation and Investments in Energy Markets: Solutions for the Mediterranean; Academic Press: Cambridge, MA, USA, 2015.

76. Hill, J. Another Solar Module Factory in Algeria. PV-Magazine. 2020. Available online: https://www.pv-magazine.com/ (accessed on 20 May 2020).

77. MEED. Algeria Plans to Build \$3bn Solar Project. Power Technol. 2020. Available online: https://www.power-technology.com/ comment/algeria-plans-3bn-solar-project/ (accessed on 11 June 2020).

78. World Small Hydropower Development Report 2016; United Nations Ind Dev Organ Vienna, Int Cent Small Hydro Power: Hangzhou, China, 2016. Available online: https: / / www.unido.org/ (accessed on 12 June 2020).

79. Arabstoday. Government Closes Hydropower Plants to Save Water in Algeria. 2014. Available online: https://www.arabstoday. net/en/182/government-closes-hydropower-plants-to-save-water-in-algeria (accessed on 3 June 2020).

80. Laouari, A. Hydropower in Algeria: Current Status and Future Opportunities. Int. J. Hydropower Dams. 2017, 24. Available online: https:/ / www.hydropower-dams.com/articles/hydropower-in-algeria-current-status-and-future-opportunities/ (accessed on 12 June 2020).

81. Algeria's Solar and Wind Power Industries Grow. Oxford Bus Gr. 2019. Available online: https://oxfordbusinessgroup.com/ (accessed on 12 June 2020).

82. Inès Magoum. ALGERIA: Towards an Agreement with Germany to Join Desertec Project. Afrik21. 2020. Available online: https:/ / www.afrik21.africa/en/algeria-towards-an-agreement-with-germany-to-join-desertec-project/ (accessed on 12 June 2020).

83. Algeria: Renewable Energy Development Program to Create 200,000 Jobs 2011. Available online: https://www.ilo.org/global/lang-en/index.htm (accessed on 12 June 2020).

84. Shahan, Z. No Joke-Algeria Plans 4 Gigawatt, 5 Year Solar Power Initiative. CleanTechnica 2020. Available online: https: / / cleantechnica.com/2020/05/27/no-joke-algeria-plans-4-gigawatt-5-year-solar-power-initiative/ (accessed on 12 June 2020).

85. Juchau, C.; David, S. Employment Estimates in the Energy Sector: Concepts, Methods, and Results. Energy Policy Inst. 2013. Available online: https://gggi.org/site/assets/uploads/2020/06/Employment-Assessment-of-Renewable-Energy_Web_final. pdf (accessed on 12 June 2020).

86. Inès Magoum. ALGERIA: Teacher Training College for Renewable Energies to be Established Soon. Afrik 21. 2020. Available online: https:/ / www.afrik21.africa/en/algeria-teacher-training-college-for-renewable-energies-to-be-established-soon/ (accessed on 13 June 2020).

87. Mahmoudi, H.; Abdellah, O.; Ghaffour, N. Capacity building strategies and policy for desalination using renewable energies in Algeria. Renew. Sustain. Energy Rev. 2009, 13, 921-926. [CrossRef]

88. Naima, K. The Future of the Application of Nanotechnology in Supporting the Use of Alternative Energies to Achieve Sustainable Development. 2018, 45, 34-43. Available online: https://link.springer.com/article/10.1007/s11051-013-2044-0 (accessed on 12 June 2020).

89. Bouznit, M.; Pablo-Romero, M.D.P. $\mathrm{CO}_{2}$ emission and economic growth in Algeria. Energy Policy 2016, 96, 93-104. [CrossRef] 